\title{
The variable expression of future tense in Peninsular Spanish: The present (and future) of inflectional forms in the Spanish spoken in a bilingual region
}

\author{
José Luis Blas Arroyo \\ Universitat Jaume I
}

\section{A B S T R AC T}

\begin{abstract}
In line with trends observed in other Spanish and Romance-speaking regions, the morphological future tense MF (cantaré) is declining in the Castellón speech community (Spain) in favor of the periphrastic variant PF (voy a cantar) for the expression of future events. The multivariate analysis shows the relevance of some linguistic factors in this process, mainly the degree of proximity of the act of speech, the sentence and epistemic modality, the degree of adverbial specification, the class of verbs and, to a lesser extent, the semantic category of the subject (agency), and the types of clause and text. All in all, MF still enjoys a substantial vitality in this Spanish region unknown in other Hispanic areas and that can be related to a convergence process with Catalan, the other language of the region which shares a single variant for expressing the future, namely, the morphological form. Some additional data obtained from 191 interviews of the Sociolinguistic Corpus of Castellón (CSCS) point out the relevance of social factors related with the density of the bilingual population in the speech community, both at the collective and individual levels. The vernacular profile of this MF, favored and retained for the most autochthones elements of society, also clashes with the sociolinguistic profile of this variant in other Spanish-speaking areas where the process of substitution has been described in many cases as a change for below. In sum, language contact can slow down and alter some linguistic change much more advanced in monolingual communities.
\end{abstract}

A number of different studies have pointed out that the variability that exists in the way the future tenses are expressed in Spanish today represents an advanced stage of a long process of linguistic change whose origins date back to the 16th century. Some see it as the result of a cycle in which synthetic and analytic solutions have alternated in the development of languages throughout history (Givon, 1971; Lyons, 1978; Marcos Marín, 1984; Schwegler, 1990; etc.). ${ }^{1}$ Because of this change, which other Romance languages have also experienced (Cartagena, 1995-96; Gougenheim, 1971; Poplack \& Malvar, 2007; Poplack \& Turpin, 1995), the morphological future tense (Viajaré a Nueva York "I will travel to

I would like to thank the members of the Sociolinguistic Laboratory of the Universitat Jaume I for the invaluable effort in field work and transcription tasks that has allowed to compile the Sociolinguistic Corpus of Castellón (CSCS). And many thanks also to two anonymous reviewers for their insightful comments on an earlier version of this paper. 
New York") has lost important areas of usage in favor of other variants, such as the periphrastic future (voy a viajar) and, to a lesser extent, the present simple with a prospective value (viajo). On the other hand, this inflectional variant is becoming functionally specialized and consequently it conveys meanings that are essentially modal (Fleischman, 1982; Montes Giraldo, 1962).

Despite the relevance of these data, which point to the existence of an important change in the way the future tense is expressed, a significant number of the books on Spanish grammars only include the inflectional forms, that is, the so-called future simple (amaré) and the future perfect (habré amado "I will have loved") as examples of the future tenses. The same tendency is repeated in grammatical descriptions of other Romance languages, such as French and Portuguese (Poplack \& Malvar, 2007; Poplack \& Turpin, 1995).

From a dialectal point of view, the process seems particularly advanced in the Spanish spoken in Latin American speech communities, if we are to judge by the references that can be found in studies on dialectology, and more recently also, in the variationist framework. Examples of such studies include those that analyze the cases of Spanish in Argentina (Sánchez \& Ferrer, 1990; Vidal de Battini, 1964), Chile (Oroz, 1964; Silva Corvalán \& Terrell, 1989), Cuba (Paufler, 1977), Puerto Rico (Silva Corvalán \& Terrell, 1989; Zentella, 1997), Colombia (Flores, 1964; Montes Giraldo, 1962; Orozco, 2005), México (Ávila, 1968; Gutiérrez, 1990, 1994, 2002; Lope Blanch, 1983; Moreno de Alba, 1970, 1978; Valdez, 1969), Venezuela (Iuliano, 1976; Iuliano \& De Stefano, 1979; Sedano, 1994; Silva Corvalán \& Terrell, 1989), Dominican Republic (Silvia Corvalán \& Terrell, 1989), United States (Gutiérrez, 1990, 1995, 2002), among other countries. Occasionally, some authors have even claimed that the inflectional future has disappeared in certain areas. Zentella (1990), for example, stated this to be the case in certain Hispanic speech communities (Dominican, Colombian, and Puerto Rican) in the city of New York. ${ }^{2}$

In Spain, the prevailing impression - at least the one we get intuitively-is that the prospective uses of the inflectional future still enjoy a certain degree of vitality. Unfortunately, empirical data that can be used to back up this statement are now far scarcer than the data available for Latin America. Furthermore, except for the Canary Islands, where some fairly valuable studies have been conducted in recent years (Almeida \& Díaz Peralta, 1998; Díaz Peralta, 1997; Díaz Peralta \& Almeida, 2000; Troya, 1998) the data are mostly derived from counts based exclusively on written texts (Bauhr, 1992; Berschin, 1987; Blas Arroyo, 2000; Cartagena, 1995-96; Eberenz, 1992; Sáez Godoy, 1968; Söll, 1968) or are propped up by simple overall estimates of frequency rates (Gómez Manzano, 1988; Lamíquiz, 1986). Hence, we know very little about the real strength of this future form in Peninsular Spanish and even less in regions where this language is used alongside others and where, as a result, it is not unreasonable to suppose that it is influenced in a similar way to that detected in several regions of Latin America.

One of the main objectives of this study is to fill this gap with a detailed analysis of a sufficiently comprehensive and representative corpus of spoken Spanish 
in a region in the east of the Spanish peninsula. Castellón is the most northerly province in the Valencian region, an area where Spanish has lived for centuries alongside another Romance language, Catalan, in the variety known as Valencian. In particular, some preliminary empirical data (Ramírez \& Blas Arroyo, 2000), as well as a number of references in the literature about the Spanish spoken in other Catalan-speaking territories (Blas Arroyo, 2004; Wesch, 1997), had previously called attention to the considerable vitality of the inflectional future forms in these areas of eastern Spain. To date, however, they have not been corroborated by sufficiently convincing empirical evidence.

In this context, then, our aims are to

1. determine the significance of the linguistic and extralinguistic factors that make up the variable context in which our linguistic variable operates in this peninsular dialect;

2. confirm whether the meaning of this significance is qualitatively or quantitatively similar to that observed in other speech communities in the Hispanic world;

3. evaluate the extent of the supposed vitality associated to the inflectional future in this variety, which, if it were to be confirmed, would represent an important exception in the general pan-Hispanic scene; and

4. evaluate the possible influence that the language contact could have on the retention of variants that are submitted to swifter processes of linguistic change in other dialectal domains.

In this article, we describe the interpretative framework in which our research can be included, as well as the main methodological issues related to the empirical study. After justifying some exclusions, the central body of our work will be devoted to the analysis of the findings. The article will end with a summary of the main conclusions to be drawn from the study.

THE VARIATION APPROACH IN THE ANALYSIS OF THE

SPANISH FUTURE TENSE

Defining the scope of the usages of the future tense with precision is a complicated task in any language. This is largely due to the very nature of its meaning, because even events that the speaker sees as being sure to occur remain within the realm of what is possible and not real, in contrast to what happens with the past tenses, for example (Coseriu, 1973:172; Fleischman, 1982:13; Molho, 1975:300). Deictic (temporal) and modal aspects therefore often coexist in the expression of the future.

However, the specialized literature contains a number of proposals based on different theoretical and methodological approaches that link the use of the two forms of the future tense to diverse linguistic and extralinguistic factors. Thus, for example, it is been noted, even within prevariationist approaches to analysis, that the use of the periphrastic variants is even more frequent in children's speech than in the language of adults (Gili Gaya, 1964; Kernan \& Blount, 1966; 
Naerssen, 1983). Likewise, it seems more common in more colloquial and "careless" registers of the language and, in general, among speakers with a lower level of education (Gili Gaya, 1964). In contrast, it has been claimed that the frequencies of use of the inflectional future increase, generally speaking, as the level of formality in speech rises (Álvarez \& Barros, 1981:8; Díaz Peralta, 1997:196; Hernández, 1971:32; Silva Corvalán \& Terrell, 1989:206), and it is still seen as the preferred form in written language (Berschin, 1987:101; Sedano, 1994:238).

From the linguistic point of view, several factors that could condition the choice of the future tense variants in Spanish have also been reported. These include whether the action is to take place in an immediate or distant future (Cartagena, 1978; Fleischman, 1982; Iuliano \& De Stefano, 1979; Rojo, 1974), the determination or indeterminacy of the moment the action is expected to occur in (Silva Corvalán \& Terrell, 1989), the degree of temporal and/or psychological "connection" with the speaker's present (Bauhr, 1989; Berschin, 1987; De Jonge, 1995; Fleischman, 1982), and so forth. From there, many have considered the inflectional future as being the most neutral or unmarked form, because it serves to express future events that do not appear as a prolongation of the act of speech. Furthermore, it is suitable for talking about events that the speaker is not sure whether they will take place. In contrast, the periphrastic form appears to be associated to the values of immediacy, proximity to the act of speech, intentionality, or the speaker's conviction that the events situated in a future time will be performed.

Regardless of the validity we could grant the foregoing proposals, it must be pointed out that the way some deal with the problem of alternation is not free of certain shortcomings that can diminish the value of their conclusions. One problem, for example, stems from the fact that, in many cases, they only come down to the linguist's own intuition. There is therefore no guarantee whatsoever that they are not going to be contradicted in other corpora. This difficulty, becomes obvious, for example, when contradictions are detected among different authors with regard to the validity of a certain criterion. In addition, empirical evidence exists to prove that the distinctions that operate in the linguistic system do not always appear openly in real data. In other words, on occasions they are neutralized in discourse, thus favoring the alternation between different forms.

In the study of variability, the variationist paradigm is rooted in theoretical and methodological principles that are different from those usually found in linguistic hermeneutics. Instead of hypothesizing that certain semantic or pragmatic contents are enclosed within this or that variant, the variationist model postulates that variability can only be interpreted by studying it in context. This context, which necessarily has a variable content, is determined by a combination of different linguistic and nonlinguistic factors, which must also be taken into account at the same time to be able evaluate their true explanatory power. The use of a suitable method, such as the one we will describe in the following section, makes it possible to account for not only the significance of each of these criteria in 
explaining variability, but also their hierarchy and the possible (in)dependence or interaction between them.

\section{METHODOLOGY}

The corpus used in this research is made of the verb forms that express events due to take place after the speech event, which are represented by the inflectional (or morphological) future (MF) and the periphrastic future (PF) tenses. Such forms have been taken from the Corpus sociolingüístico de Castellón y sus comarcas (the Sociolinguistic Corpus of Castellón and its Province) (Blas Arroyo, 2002). At the time of writing, this macrocorpus comprises 305 semidirected interviews, of which 210 have been transcribed. Sociolinguistic criteria were used to classify speakers to ensure a sufficiently comprehensive and representative sample of the Castellón community.

For this study, 191 interviews were selected using a system of sampling based on quotas of sex, age, and level of education. To complement this, other sociological factors were taken into account in a poststratification stage; these included speakers' birthplace, their dominant language, their social status, the relationship between the speakers, and so forth. Each interview lasted an average of 45 minutes, which is approximately 143 hours of recordings - a speech corpus that is extensive enough to provide significant data about a syntactic variable such as the one that concerns us here.

Following the methodology usually employed in this kind of research (Milroy, 1987), a number of topics were introduced during the course of the interviews to facilitate the appearance of future tense forms. Respondents were asked about diverse kinds of future events to satisfy our interest in analyzing the differences between distinct types of texts (see discussion of the degree of animacy of the subject and text type).

Each of the future forms was coded according to a series of linguistic and extralinguistic factors. The first of these factors are syntactic, semantic, and pragmatic criteria that have been examined in a number of previous studies, although, as far as we are aware, this is the first time that some of the others have been taken into account in relation to our variable. These linguistic factors are as follows: grammatical person, syntactic category of the subject, proximity to the speech event, sentence modality, speaker's attitude, type of adverbial specification, type of verb, semantic category of the subject, type of text (argumentative/expository), type of clause, and linguistic context (co-text). The list of extralinguistic criteria comprises the following sociological features: sex, age, level of education, social status, type of profession, dominant language, and place of origin.

Finally, all the data were submitted to a multivariate logistic regression analysis, carried out using the statistics application GoldVarb 2001 for Windows (Robinson \& Tagliamonte, 2001). As our main analytical object, we take the inflectional future as the application value throughout the study. 


\section{EXCLUSIONS}

For this study, we only took into consideration occurrences of the verbal variable where a clear temporal content was observed, regardless of the fact that certain forms may also include additional meanings of a modal or aspectual nature. Thus, we deliberately left out a number of uses where both the inflectional and the periphrastic forms were employed but in which neither the idea of prospective temporality is apparent nor could they be replaced by the alternative form in contemporary Spanish.

This is the case, for instance, with the different modal values acquired by the MF forms when they lose the vector of posterity and take on nuances that indicate uncertainty (surprise, conjecture, probability, necessity, etc.) (Rojo \& Veiga, 1999:2895), as can be seen in example (1). This idea also underlies certain syntactic schemas that are frequent in oral Spanish, such as the utilization of the future tense with a modal rather than prospective value in adversative and concessive sentences. In such cases, as in example (2), the uncertainty introduced by the morphological future gives rise to a metalinguistic comment that questions the other participant's utterance. Finally, our empirical analysis will not consider uses of the future tense that are clearly determined by interference from Catalan within our community, as is the case of subordinate time clauses. In this case, the subjunctive is the correct form in Spanish, whereas in Catalan the morphological future tense is used, as can be seen in (3) (for more details, see "Nonstructural factors"):

(1) ... y dices: "Uy, este [chico] tendrá mala leche o" pero luego sales por ahí con él $\mathrm{y}$ (es) totalmente diferente $(15 / 205)$

... and you say, "Oh, he's probably be [a] nasty [guy]" but then when you're out with him [he turns out to be] completely different ${ }^{3}$

(2) [su trabajo] no será duro ipero él llega agota(d)o todos los días a casa! (215/354) [his job] isn't hard but he gets home exhausted every day!

(3) Eso le decía anoche a Luis, digo "el problema será cuando iré, que cuando iré, entonces sí que, sí que ya me saldrá con todos los males $(293 / 30)$

That's what I told Luis, I said, "the problem's going to be when I go, when I go, then he'll start to tell me everything that's wrong with me"

Utterances containing the PF were left out when the verb ir (go) maintains its original lexical value, as in (4), in which the periphrasis takes on a frequentative aspectual value. Similarly, we did not consider certain pragmatic uses conveyed by the periphrasis, such as the "replicative" value seen in (5), which can be used to reject a statement or supposition by means of an emphatic rhetorical question or an exclamation (Cartagena, 1999:2968). Likewise, the presence of ir a (going to) plus infinitive — example (6) - in the protasis of conditional sentences has not been included in our analysis, because in this syntactic context the morphological future tense is not possible (si vendrás ... "if you'll come ...”). 
(4) ... incluso sábados que no me toca trabajar, voy a trabajar [a la empresa] por no limpiar en casa $(91 / 115)$

... even on Saturdays when I don't have to work, I go to work [at the business] so I don't have to do the cleaning at home

(5) ... ipero qué te van a decir! No seas tonta $(215 / 367)$

... but what did you expect them to say to you! Don't be silly

(6) ... si vas a venir, dímelo antes (202/887)

... if you're going to come, let me know beforehand

Utterances in which either of the two forms, despite displaying a clear temporal meaning, represent quasi-categorical variants in current Spanish with a very limited or no capacity to alternate were also left out of our analysis. Such is the case with certain lexicalized formulae, usually with the periphrasis (a ver si. . "let's see if," vamos a ver "let's see," vete a saber "God knows," iqué le vamos a hacer! "what can we do about it?," ¡dónde va a parar! "what's the world coming to?"), but also with the morphological future tense ( $y$ a veremos "we'll see"). Although the action expressed by the verb is seen as occurring after the act of speech in all these examples, their construction in contemporary Peninsular Spanish appears to be fixed by usage to one of the variants considered in the study, with no possible alternation between forms.

RESULTS AND ANALYSIS

\section{General results}

As a result of the exclusions documented in the previous section, the 4046 occurrences of future forms found in the corpus were finally reduced to 2045 , and we can now be sure that we are dealing with forms that are wholly relevant to the variable under study.

Of these, a first analysis showed that 1134 correspond to cases of MF, and the remaining 911 are examples of PF tense. This result came as some surprise, because, as we have seen earlier, counts performed in other Hispanic speech communities have shown that the inflectional variant is clearly losing ground. Even in areas where this variant has been seen to be offering a certain degree of resistance, the figures obtained in empirical studies on the subject are far lower. Thus, in northern Colombia, Orozco (2005) reports a figure of $18.2 \%$ for cases linked to MF vs. $45.9 \%$ for the use of PF. Even in Spain, where grammarians have traditionally conferred a certain degree of strength on the former-a vigor that is now largely unknown in much of Latin America-it is difficult to find similar samples in anything other than the written language (Blas Arroyo, 2000). Although the absence of variationist studies on the Spanish peninsula hampers any kind of comparison, authors such as Díaz Peralta and Almeida (2000) have recently drawn attention to the revitalization of the inflectional future in some varieties in the Canary Islands (Gran Canaria). According to these authors, this change from above is driven, among other reasons, by imitation of the more 
prestigious models from the peninsula. Nevertheless, barely a decade ago, the figures for the MF tense within this same speech community were much lower and only just exceeded $18 \%$ of the total number of occurrences of the future tense (Almeida \& Díaz Peralta, 1998).

The criteria the statistics program found to be significant in this first analysis include one factor, co-text, that measures the eventual influence of the surrounding linguistic context. Some sociolinguistic and psycholinguistics studies have paid attention to the powerful influence of this factor to explain speakers' persistent use of the same variants in neighboring contexts. This "birds of a feather" (Pereira-Scherre, 2001), or "perseveration" effect (Cameron \& Flores Ferrán, 2004), has been shown to be statistically significant in several cases of linguistic variation and has a recurrent pattern, due, in many cases, to psycholinguistic, unintentional reasons. "The presence of one variant at one point in the linear sequence may trigger subsequent strings of similar forms or structures" (Cameron \& Flores Ferrán, 2004:43).

To test the importance of this structural factor in our corpus, we are initially faced with two possibilities.

1. To use the same form that was employed in the previous co-text, either by the same speaker (7) or by the interlocutor in the next turn, as in (8):

(7) Bueno, de aquí a treinta años creo que la gente dejará de ir ..., porque será un lujo una persona que ... ni fume, ni beba, ni ni vaya por esos sitios $(380 / 120)$

Well, I think that in thirty years' time people will stop going ..., because it'll be a luxury for a person who ... doesn't smoke, doesn't drink, doesn't go to that sort of place

(8) I: ¿Cuál vas a leer?

Which one are you going to read?

R: Voy a leer un compendio de libros de Pérez Reverte que se llama Obra Breve $(95 / 410)$

I'm going to read a compendium of books by Pérez Reverte called Obra Breve

2. To select a variant other than the one that was used previously:

(9) I: (laughs) Y ¿este verano qué vas a hacer? ¿Te vas de viaje o te quedas aquí?

And what are you going to do this summer? Are you going away or staying here?

R: Pues este verano me iré a la playa, que tengo una casita (380/114)

Well, this summer I'm going to the seaside because I've got a little villa there

The findings of this analysis are very enlightening, because in no fewer than 703 cases ( $83 \%$ of the total) speakers apply this rule of perseveration, which involves using the same future variant as the one that appeared in the previous co-text, vs. only $144(17 \%)$ in which the alternative is used. Now, the presence of almost 
twice as many occurrences of the MF in this context (548 vs. 299 of the PF) explains why this factor has necessarily far more explanatory power in the inflectional variant than in the periphrastic one.

In summation, in a rigorous analysis, we cannot rule out the possibility that the incidence of this factor seriously "contaminates" the general results obtained for the others. Consequently, and in order to exclude the relevance of this perseveration effect, we undertook a new count, this time taking into account only the future variants that appear isolated in discourse or in sentences that are sufficiently separated from one another to avoid the risk of a possible attraction due to proximity.

The results of this second empirical analysis can be seen in Table 1 under the heading "After recoding." The robustness of the morphological future is again confirmed, with an adjusted mean of 0.46 , which is still one of the highest figures observed in the Hispanic world. However, it is now the PF that appears as the most frequent variant (adjusted mean 0.54), which is more in line with the trends observed in other Hispanic regions.

Table 2 shows the probabilistic weight of the factors found to be significant by the multivariate analysis, together with their hierarchical arrangement. An initial review of our data reveals the greater significance of the linguistic factors, particularly in the case of some that have already been analyzed in the literature, such as the degree of temporal proximity, the type of adverbial specification, or certain lexical-semantic traits, such as the modality or the type of verb. Yet, the empirical study also shows the importance of other criteria that have not received the same attention in the past and that, nevertheless, exert their incidence on the rule of variation we are dealing with here. These include a number of extralinguistic factors that display characteristics that perhaps help to account for the vitality shown by the morphological future in the speech communities of Castellón.

In the following paragraphs, we provide a thorough analysis of these and other factors. ${ }^{4}$

\section{Linguistic factors}

The temporal distance. The first of the linguistic factors we are going to consider concerns the separation in time, or temporal distance, between the act of speech and the event expressed by the verb - a criterion often proposed as the most important for distinguishing between the uses of MF and those of PF forms. Thus, PF has traditionally been linked to the expression of close or imminent actions or processes, but MF is the preferred variant for distant time

TABLE 1. Distribution of the inflectional future $(M F)$ before and after recoding

\begin{tabular}{llll}
\hline \hline \multicolumn{2}{c}{ Before recoding } & \multicolumn{2}{c}{ After recoding } \\
\hline$\%$ & $(\mathrm{~N})$ & $\%$ & $(\mathrm{~N})$ \\
55 & $(2045)$ & 46 & $(1122)$ \\
\hline \hline
\end{tabular}


TABLE 2. Contribution of the linguistic and extralinguistic factors ${ }^{a}$ found to be significant in choosing the inflectional future (MF) form in the districts of Castellon ${ }^{b}$

\begin{tabular}{|c|c|c|c|}
\hline Temporal proximity & & Probability $^{c}$ & $\%(N)$ \\
\hline \multicolumn{4}{|l|}{ Temporal proximity } \\
\hline Closeness (day) & & .34 & $34(229)$ \\
\hline Intermediate distance & & .47 & $51(33)$ \\
\hline Attenuated distance & & .41 & $50(48)$ \\
\hline Indefinite distance & & .44 & $40(541)$ \\
\hline Maximum distance & & .73 & $73(271)$ \\
\hline Range & 39 & & \\
\hline \multicolumn{4}{|l|}{ Sentence modality } \\
\hline Affirmative & & .56 & $51(752)$ \\
\hline Negative & & .40 & $38(188)$ \\
\hline Interrogative & & .35 & $48(66)$ \\
\hline Indirect interrogative & & .43 & $45(57)$ \\
\hline Exclamatory-exhortatory & & .27 & $27(59)$ \\
\hline Range & 29 & & \\
\hline \multicolumn{4}{|l|}{ Speaker's attitude } \\
\hline Certainty & & .40 & $38(263)$ \\
\hline Intention & & .32 & $37(187)$ \\
\hline Opinion & & .46 & 45 (177) \\
\hline Uncertainty-contingency & & .62 & $58(495)$ \\
\hline Range & 30 & & \\
\hline \multicolumn{4}{|l|}{ Type of adverbial specification } \\
\hline No specification & & .45 & $39(694)$ \\
\hline Precise specification & & .49 & $60(173)$ \\
\hline Imprecise specification & & .56 & $60(202)$ \\
\hline Specification using quantifiers & & .78 & $64(53)$ \\
\hline Range & 33 & & \\
\hline \multicolumn{4}{|l|}{ Type of verb } \\
\hline Periphrasis & & .64 & $56(37)$ \\
\hline Modals & & .75 & $79(54)$ \\
\hline Movement & & .63 & $62(124)$ \\
\hline Sensory perception & & .66 & $62(32)$ \\
\hline Psychological & & .55 & $52(92)$ \\
\hline Stative & & .47 & $51(187)$ \\
\hline Language & & .45 & 35 (112) \\
\hline Others & & .43 & $39(484)$ \\
\hline Range & 32 & & \\
\hline \multicolumn{4}{|l|}{ Semantic category of the subject } \\
\hline Human & & .50 & $48(747)$ \\
\hline Human (generic) & & .35 & $31(122)$ \\
\hline Nonhuman & & .57 & $54(253)$ \\
\hline Range & 22 & & \\
\hline \multicolumn{4}{|l|}{ Type of clause } \\
\hline Subordinate & & .38 & $44(486)$ \\
\hline Others & & .57 & $56(636)$ \\
\hline Range & 19 & & \\
\hline \multicolumn{4}{|l|}{ Type of text } \\
\hline Argumentative & & .43 & $41(475)$ \\
\hline
\end{tabular}


TABLE 2. Continued

\begin{tabular}{|c|c|c|c|}
\hline Temporal proximity & & Probability $^{c}$ & $\%(N)$ \\
\hline Expositive & & .57 & $55(438)$ \\
\hline Range & 14 & & \\
\hline \multicolumn{4}{|l|}{ Place of origin } \\
\hline Province & & .53 & $50(559)$ \\
\hline Castellón town & & .49 & $48(432)$ \\
\hline Immigrants & & .37 & $39(131)$ \\
\hline Range & 16 & & \\
\hline \multicolumn{4}{|l|}{ Social status } \\
\hline Upper-middle & & .40 & $41(203)$ \\
\hline Lower-middle & & .55 & $51(446)$ \\
\hline Low & & .49 & $48(408)$ \\
\hline Range & 15 & & \\
\hline \multicolumn{4}{|l|}{ Age } \\
\hline Under 40 years of age & & .41 & $44(728)$ \\
\hline Over 41 years of age & & .55 & 55 (394) \\
\hline Range & 14 & & \\
\hline Logarithmic likelihood $=-632.843$ & & & Significance: 0.027 \\
\hline
\end{tabular}

Note: Total $N(/$ variant $)=1122(537) ;$ Corrected mean $=.466$.

${ }^{a}$ Factor groups not selected: grammatical person, syntactic category of the subject, sex, level of education, type of profession, dominant language.

${ }^{b}$ Data analyzed using GoldVarb 2001 (Robinson \& Tagliamonte, 2001).

${ }^{\mathrm{c}}$ The highest probabilities in each factor group are highlighted in bold type and the lowest are marked in italics. Probabilities that are identical or only have slightly significant differences appear unmarked.

contexts: contexts that are further away from the act of speech. The more traditional grammars coincide on this point in Spanish (Fernández Ramírez, 1986; Gili Gaya, 1964; R.A.E., 1973) and in other Romance languages (Grevisse, 1986; Wagner \& Pinchon, 1974), as do other more recent researchers (Cartagena, 1978; Iuliano \& De Stefano, 1979; Silva-Corvalán \& Terrell, 1989).

However, different empirical studies carried out in recent years, in such distinct Romance communities as Canadian French (Poplack \& Turpin, 1999), Brazilian Portuguese (Poplack \& Malvar, 2007), or Venezuelan Spanish (Sedano, 1994) have proved that $\mathrm{PF}$ is also used for the general expression of futurity. In fact, in many speech communities, it is the unmarked way of doing so. Sedano (1994), for example, saw how the PF variant in Venezuela is not only categorical in contexts of immediate proximity (100\%) and quasi-categorical (86\%) in those involving a "relatively near future," but it is actually clearly preferred even when the time stated is very remote from the act of speech (64\%). In a rather more conservative speech community (Northern Colombia), Orozco (2005) also observed how the PF tense is clearly used more frequently (41\%) than the inflectional future form (25\%) in distant or indefinite contexts.

Nevertheless, it must be remembered that the time criterion is not univocal and may therefore be reinterpreted by speakers according to their affective or 
psychological motivations. Thus, Berschin (1987) has related the proximity/ distance factor to the concept of connection. According to Berschin, the connection between the verbal event and the act of speech can be of a spatial and/or situational nature rather than just temporal. The variation rule under study here nevertheless holds true for this linguist in its basic functional principles. "In the first case (positive connection) the analytical future form is preferred, while in the second (negative connection) the synthetic future is favored" (p. 104). On the other hand, Bauhr (1992:72-73) also linked this connectivity or proximity, not so much to the notion of temporality in absolute terms but rather to the "psychological" tie, with the speech event that the speaker assigns to the action being described (see also De Jonge, 1995; Fleischman, 1982). For example, with respect to the conception of a child by a woman (voy a tener un hijo "I'm going to have a baby"), which is not necessarily immediate or even in a near future, this researcher underlines the fact that "in this context it can be stated that ir $a+$ infinitive is the only possible form according to the general linguistic norm in Spanish, although the event of 'having a baby' is not seen as being immediate" (our italics).

In any case, it is often difficult to decide the degree of psychological linkage or connection between what is said by speakers and the moment of speech. Sometimes key elements needed to be able to decide on the level of temporal proximity that speakers grant their verbal acts are missing.

To avoid excessive subjectivism, in this study we have conducted the empirical analysis of the temporal context using criteria that are as objective as possible, and not on the basis of the semantic value supposedly inherent in each form. In accordance with this principle, we divided the time axes traced by the utterances in our corpus into a number of series that range between the following extremes: (a) realization immediately after the speech event and (b) events that are expected to take place centuries later.

In agreement with Poplack and Turpin's (1999) approach to the analysis of this linguistic variable in Canadian French, we classified the temporal forms of our corpus in different groups based on the following criteria.

1. Events that are expected to take place in the immediate future or, at the most, in the hours following the act of speech, the limit being the day on which the act is performed:

(10) ... dentro de diez minutos me acordaré de algo, ahora no me acuerdo $(18 / 538)$

in 10 minutes' time I'll remember something, right now I can't remember

(11) ... porque le está preguntando una cosa y el profesor ee ... le va a tener que contestar, ¿no? (217/580)

because he's asking him something and the teacher erm ... he's going to have to answer, isn't he?

2. Events expected to take place at a much later date than those in the previous paragraph. We also thought it advisable to distinguish between different 
degrees within these cases to account for both the purely temporal aspects and those of a psychological nature we referred to earlier. In this way, the axis of events that are remote in time is structured as follows.

a. Actions or states that are expected to come about in the days following the moment of speech. For the purposes of the comparative analysis and coding its results in this study, we called this factor "intermediate distance," that is, a future objectively situated at an intermediate position between the imminence or proximity of (a) and the maximum distance of the facts described in (c). These are some examples from the corpus:

(12) ... yo además el próximo día [de clase] hablaré con micrófono porque si no no se me oye $(217 / 583)$

besides, the next day [of class] I'm going to speak with the microphone because if not I don't make myself heard

(13) ... yo este fin de semana voy a salir con mil pesetas porque en vez de de tener dos millones ... (123/1028)

this weekend I'm going to go out with a thousand pesetas because instead of having two million ...

b. Actions or states that are objectively situated at a more remote point in time, but which psychologically display a certain degree of closeness to the present of speech due to the presence of certain elements in the immediate linguistic context. In the following utterances, for example, the speakers refer to events that are due to take place several months after the interview by using the demonstrative este (este verano ... "this summer ..."), which is used in Spanish to determine references that are more closely associated to spatial and/or temporal proximity (Alcina \& Blecua, 1975:§4.3; Lamíquiz, 1987:149). Although the speakers could have deployed other possible means of expression-"el próximo verano ..." (next summer), "en verano ..." (in summer) - they chose the alternative that exhibits the strongest link to the deictic center of speech. In the paragraphs that follow, we refer to this factor as "attenuated distance."

(14) ...este verano, pues no sé, no sé a dónde iremos pero yo creo que a un sitio u otro, soy de una ... (332/1137)

this summer, I don't know, I don't know where we'll go but I think we'll go somewhere, I'm from a ...

(15) ... esa es la única cosa que voy a hacer este verano (396/1209) that's all I'm going to do this summer

c. Actions and states that are expected to take place at a time that is clearly distant from the present and, at any rate, temporally and psychologically further away than the previous cases. For the sake of clarity here, we will call it "maximum distance."

(16) ... si el año que viene me matriculo de francés tendré que empezar desde segundo ... porque tercero ... (236/1297)

if I enroll in French next year I'll have to start in the second year ... because the third... 
(17) ... no sé si no la voy a sacar [la carrera], porque con el trabajo y todo tengo poco tiempo para estudiar (129/1394)

I don't know whether I'll finish [my degree], because what with work and everything I haven't got much time to study

d. Lastly, we set up a specific group for actions and states that, though also situated in a position a long way from the act of speech, nevertheless display temporal profiles that are blurred. This occurs because it is impossible for both the speaker and the listener to locate them in an objective manner. This "timeless"-if the reader will excuse the apparent contradiction-or vaguely delimited future appears, for example, in fragments of an argumentative nature such as (18) and (19), in which the interlocutor is asked for an opinion on the hypothetical introduction of a law to reduce the working week to 35 hours for Spanish workers sometime in the future. On answering, the speaker logically situates opinions and the facts related to them in an imprecise future, because there are no data that allow them to be set at a definite moment in time. In short, they are distant but indefinite contexts. From here on, we refer to this factor as "indefinite distance."

... porque si trabajamos 35 horas cobraremos menos (316/606)

... because if we work 35 hours we'll get paid less

... A(ho)ra, si con 35 horas va a suponer que el paro se redujese en una cifra estimable, pues considero que sí merece la pena $(389 / 221)$

... Now, if 35 hours is going to mean a considerable drop in unemployment figures, then I think it is worthwhile

As seen in Table 2, the MF form is only significantly more frequent in the contexts we have categorized as "maximum distance," that is to say, the ones that are temporally and/or psychologically furthest away from the speech event. In $73 \%$ of these cases, the speaker chose the morphological variant, which explains why this factor has one of the highest probabilistic weights $(0.73)$ of all those considered in the study. Therefore, we are before one of the main loci in which the inflectional future form is used and which at least partially accounts for the vitality displayed by this form in the Castellón speech community.

In contrast, the other factors considered in this analysis show a negative incidence on the choice of MF, a finding that is found not only in "close" contexts, with the lowest probability $(0.34)$, but also in the other-objective"distant" contexts. Although to a lesser extent, the statistical significances of intermediate distance $(0.47)$, indefinite distance $(0.44)$, and attenuated distance (0.41) are also negative.

Hence, except for the remotest contents, the empirical results show that the inflectional future form is not exclusively used to express facts that are neither close nor immediate; instead they are temporal contexts that favor to a greater extent other future variants, such as the PF form. This coincides with what has been observed in other regions where Romance languages, such as Canadian French, are spoken (Poplack \& Turpin, 1999). 
Type of adverbial specification. A number of authors have drawn attention to the positive correlation, in Spanish (Bauhr, 1992; Orozco, 2005; Sedano, 1994; Silva-Corvalán \& Terrell, 1989) and in other Romance languages (BlancheBenveniste, 1990; Poplack \& Malvar, 2007; Poplack \& Turpin, 1999; Sundell 1991), between variable expression of future tense and the type of adverbial specification that can accompany the expression of futurity. In this regard, it has been claimed that MF is preferred in cases of indetermination. Unfortunately, the possible interpretations concerning this factor do not always coincide. For instance, Silva-Corvalán and Terrel (1989) warn that the most frequently available contexts for the morphological future in their Latin American corpus are the "indefinite" ones. That is, those in which the expression of the verb is not accompanied by any kind of adverbial phrase. In contrast, Bauhr (1992:72) observes that the form ending in -ré is often related to another element in the sentence, "which in turn indicates subsequence [...] an indication of subsequence is created that has no relation to the moment of speaking, which favors the use of the future form ending in -ré." Elsewhere this author warns that the presence of this type of adverbial phrase is absolutely essential if the inflectional forms are to appear.

To determine the scope of this factor in our corpus, we again preferred to follow the criterion adopted by Poplack and Turpin (1999) in their research into this linguistic variable in Canadian French. The two authors distinguish three factors, which correspond to the same number of contexts in which the following features are crossed.

1. The presence/absence of adverbial specification.

2. The specific/nonspecific nature of these adverbial phrases. As a result, the following contexts can be distinguished in the Castellón corpus.

a. Future verb forms that are not accompanied by any kind of adverbial phrase:

(20) ... pero bueno, al menos nos valdrá de algo estudiar, ¿no? (302/1427) well, but at least studying will be of some use to us, won't it?

(21) ... si no juegas [a la lotería] no te va a tocar (271/1421) if you don't play [the lottery] you're not going to win it

b. Verb forms that are complemented by specific adverbial phrases, such as the examples in (22) and (23):

(22) yo mañana me parece que lo más seguro (es) que me iré a pasar todo el día allí, me lo ha dicho $(302 / 1435)$

I think tomorrow I'll more than likely spend the whole day there, he said I could

(23) ... sí que me voy a ir esta noche. hay que rematar en Villarreal la fiesta que ya ... ya se acaba $(82 / 1500)$

I am going to go tonight. We have to see out the festivities in Vila-real because they're ... they're coming to an end

c. Future forms that are accompanied by a nonspecific semantic adverbial phrase, and which therefore situate the verb action at a vague, imprecise 
point on the time axis. The following examples from our corpus illustrate this point:

... cuando lo pruebe [tener un mes de vacaciones], a lo mejor pues en un año me cogeré los treinta días seguidos y ya podré saber lo que es $(269 / 1542)$

... once I try it [having a month's holiday], one year I'll probably take the 30 days together and then I'll know what it's like

(25) ... y cuando me den la cartilla de la mili le voy a pegar un viaje! $(82 / 1519)$

and when they give me my military service record card I'm throwing it as far away as I can!

d. At this point, we introduce an additional group, which somehow contributes to the semantic natures of the two preceding cases. We are referring to occurrences of the future tense that are complemented by a subtype of adverbial expressions in which temporal and aspectual values go hand in hand, such as "jamás, nunca, siempre, en la vida, mientras viva ..." (never, always, in all [my] life, while I'm still alive ...). Such adverbial phrases are what are known as "frequency adverbials" (García Fernández, 1999:3136), which indicate how often an action or state takes place, but in this particular case in a "totalizing" way, because they situate the verbal facts in an absolute-although at the same time and for that very same reason-imprecise or nonspecific future. This description can be seen more clearly in the utterances below:

(26) ... Esto no lo puedes cambiar en tu vida, puedes hacerla más amena pero siempre serás un vegetal $(77 / 1836)$

You can't change that in your life, you can make it more pleasant but you'll always be a vegetable

(27) ... Tienes el dinero que quieras, puedes emplearlo en lo que quieras y nunca te va a faltar de nada (24/2061)

You've got all the money you want, you can spend it on whatever you like and you're never going to be short of anything

As in other oral speech corpora, this linguistic factor also appears among those with the highest significance (range 33) in the Castellón corpus. On the one hand, the multivariate regression analysis shows the positive association between MF and contexts in which there is some kind of adverbial phrase, especially of a nonspecific nature (0.56), but above all with quantifying adverbial expressions (never, always, in all my life ...), which have one of the highest degrees of significance of all those considered in the study (0.78). One possible explanation for this finding lies in the very nature of such adverbial phrases, which have an unspecific scope that tends to extend ad infinitum. The cases in which MF is accompanied by specific adverbials, however, display a significance that is practically neutral (0.49).

On the other hand, the absence of adverbial phrases disfavors the use of MF (0.45), but PF is favored (0.55) by this circumstance. It is within this context that 
$\mathrm{PF}$ is most commonly found, because it represents $61 \%$ of all occurrences of the future variable. At the same time, it also constitutes an additional argument for considering the PF form to be the unmarked variant in the Spanish verb system. In the less-marked contexts, such as those in which the future appears without any kind of adverbial, periphrasis not only acts as a means of expressing events due to take place after speaking, but is also the form that is preferred by speakers. At the beginning of its grammaticalization, the periphrastic variant had an aspectual value, but as the process developed, it gradually took over temporal usages from the inflectional future form. As a result, it no longer needs time adverbials for such tasks (Hopper \& Traugott, 1993:68).

Sentence modality. Modality is a category that some linguists have also seen as being associated with the variability that takes place in expressing the future. In this study, we analyzed the possible incidence of two classes of modality. On the one hand, we find the type of logical modality we have labeled speaker's attitude, which we shall deal with in the next section. On the other hand, we have the socalled sentence modality, which commonly includes factors such as the status of the sentence (statement, interrogation, and command), the dictum vs. modus dichotomy (modality in the strict sense of the word), and the degree to which the speaker adheres to the content of the utterance (modalization), as well as certain suprasegmental features (González, 1983; López García et al., 1988).

By crossing criteria such as those above, the grammatical tradition usually distinguishes several basic types of sentences; in our study, we have considered the following:

1. Affirmative declarative sentences:

(28) Esto se verá este verano $(202 / 275)$

This will be seen this summer

(29) ... no, desde luego vamos, vamos a hacer viajes, a mí me me encantan los viajes $(377 / 283)$

... no, of course we're, we're going to travel, I love traveling

2. Negative sentences:

(30) Es que, no sé, son cosas que no las comprenderé nunca, no ... entiendo cómo puede ser la gente $(327 / 56)$

I don't know, they're things I'll never understand, I don't ... understand how people can be like that

(31) ... en general, yo pienso que el día de mañana no va a ser feliz $(383 / 310)$ ... generally speaking, I don't think that she's going to be happy in the future

3. Exclamatory and exhortatory sentences

(32) ¡... difícilmente me tocará la lotería!, primero porque no juego ... $(211 / 574)$

... I'm not likely to win the lottery! First of all because I don't play ... 
(33) i ... vete tú a saber dónde se van a ir ellos a vivir! (327/57)

... God knows where they're going to live!

4. Interrogative sentences:

(34) ¿Qué haremos? ¿Qué haremos? ¿qué hacemos siempre? pues descansar que ... es que no $(217 / 584)$

What'll we do? What do we always do? Have a rest, no, I suppose ... the answer is no

(35) “... oye esto a ver si ya ... ¿esto cuándo va a acabar?” (217/587)

“. . . hey, it's about time this ... When's this going to stop?"

5. As a complement to this, we added another particular case of modality-that represented by indirect interrogative sentences, where some of the factors mentioned above for the other groups are crossed. So, although they are formulated as interrogative utterances, such as questions and similar speech acts, the grammatical tradition usually treats these sentences as belonging to the group of declarative sentences (more specifically as subordinate noun clauses), because the embedded clause acts as the direct object:

(36) ... pues no sé si la cabalgata la seguirán haciendo, y entonces si quitan eso pues sí ... (373/93)

... well I don't know whether they still do the procession, and so if they do away with that ...

(37) ... y se preocupa de ... en ir buscando qué libros van a dar el curso que viene $(383 / 312)$

... and he goes out of his way to, to go and find out what books they're going to use next year

By considering the sentence modality criteria, our intention is to determine whether speakers' greater or lesser involvement in their utterances, together with a higher or lower degree of certainty as regards their content, has some incidence on the variability of the future tense. One would expect the number of occurrences of the periphrastic variants (PF) to rise as the speakers' levels of emotional involvement increase, while their lower degree of subjective "connection" (Bauhr, 1992; Berschin, 1987) to the future events would still represent a productive locus for the inflectional future. It is therefore reasonable to assume that, if these conditioning factors are true, there will be significant differences, for example, between the group of affirmative and interrogative sentences, which favor the inflectional forms, ${ }^{5}$ and the one made up of exclamatory and exhortatory sentences, which will presumably tend toward the use of the periphrastic forms. This is so despite the fact that in the grammatical tradition the MF form is also associated with imperative speech acts, such as commands, orders, or prohibition (no matarás "thou shalt not kill"). ${ }^{6}$

Moreover, some linguists have related not only affirmative sentences with MF, but also negative sentences. Poplack and Turpin (1999), for example, have viewed this last modality as one of the few linguistic contexts where the morphological future tense is still used in the French spoken in Canada today. 
As expected, in our corpus the MF tense is a variant that is clearly disfavored in contexts that lead speakers to manifest a special degree of affective involvement in the content of their utterances, as occurs in exclamatory and exhortative sentences. It therefore comes as no surprise that the probabilistic weight obtained by this factor in the multivariate analysis is among the lowest of them all (0.27). However, in addition to these, the inflectional variant is also clearly disfavored in direct (0.35) and indirect (0.43) interrogatives, as well as among negative sentences (0.40), which, as we have mentioned above, are sentence types in which MF is more common in other speech communities. In contrast, in Castellón all these sentence modalities are more frequently associated to the PF form.

In contrast, utterances that are more neutral from the emotional point of view or, we could say, are less strongly connected to the subjectivity of the speaker, as is the case of affirmative sentences, represent the only modality that favors the use of the morphological future. Nevertheless, the degree of significance reached by this factor is not very high (0.56), and this is accompanied by scarce differences in frequency between the two variants (52\% for MF; $48 \%$ for $\mathrm{PF}$ ).

All the same, this is one of the most decisive linguistic factors in accounting for the vitality that the inflectional future continues to display in the Castellón speech community. The affirmative modality exhibits a slight, but positive, incidence in favor of the morphological variant. This fact, together with the overrepresentation of this type of sentence in the sample (affirmative sentences account for $67 \%$ of the total number), enables us to explain, at least partially, why the inflectional future has managed to resist in this region of Peninsular Spain.

A more detailed analysis of the available data, however, reveals a certain interaction between this linguistic criterion and the degree of adverbial specification. Thus (see Table 3), the affirmative modality favors the choice of MF in the presence of both precise $(62 \%)$ and, above all, imprecise $(67 \%)$ kinds of adverbials. Yet, in the absence of any adverbial specification, the frequencies are reversed (42\%), and now it is the PF forms that are chosen more frequently.

The speaker's attitude. In the literature on the future tense in Spanish (Bauhr, 1989, 1992; Iuliano, 1976; Naerssen, 1983; Sedano, 1994; Silva-Corvalán \&

TABLE 3. Distribution of inflectional future $(M F)$ after cross-tabulation among the factors groups affirmative modality and type of adverbial specification

\begin{tabular}{llr}
\hline \hline & & Affirmative modality \\
\cline { 2 - 3 } Type of adverbial specification & $\%$ & $(N)$ \\
\hline No specification & 42 & $(457)$ \\
Precise specification & $\mathbf{6 2}$ & $(134)$ \\
Nonprecise specification & $\mathbf{6 7}$ & $(141)$ \\
Frequency adverbials (never ...) & $\mathbf{6 5}$ & $(20)$ \\
\hline \hline
\end{tabular}

Note: The highest probabilities in each factor group are highlighted in bold type and the lowest are marked in italics. Probabilities that are identical or only have slightly significant differences appear unmarked. 
Terrell, 1989) and in other Romance languages (Bybee \& Pagliuca, 1987; Confais, 1995; Fleischman, 1982; Ultan, 1978), different authors have called attention to a link between the inflectional forms (MF) and modal content related to unreality, uncertainty, or contingency. Sedano (1994:234), for instance, has drawn attention to the fact that in Venezuelan Spanish the expression of the inflectional future is still encouraged in contexts of uncertainty: contexts that involve doubt, conjecture, or reckoning on the speaker's part. In contexts of certainty, however, this variant is very unlikely to occur. Furthermore, on referring to the so-called conditional future, in which the realization of the future event depends on the satisfaction of a previously expressed condition (si vienes, iremos al cine "if you come, we'll go to see a movie"), Silva-Corvalán and Terrell (1989) point out that in their Latin American corpus (made up of samples of speech from four countries: Chile, Venezuela, Dominican Republic, and Puerto Rico), the inflectional future is more frequent than in other contexts. Nevertheless, here too there are still considerable differences in frequency in favor of the periphrastic variant ( $73 \%$ vs. $27 \%$ ). To justify this, the authors point out that "the difference could be explained by the fact that the morphological future is felt to be more marked by doubt and this is why it seems less compatible with general conditions that are valid in any tense" (p. 195, our italics). Bauhr (1992) is even more categorical when he says that, in these contexts, the future formed with the -ré ending is more suitable than the variant consisting in ir a plus infinitive. According to this author:

... since its specific temporal value is to indicate an LE [later event] that has not connection to the present, the future formed with the -ré ending is still especially vigorous in cases in which it indicates the future consequence of another event, which at the same time is seen as being a condition for that consequence. [...] in these cases, in which the SP has a clearly contingent character due to its depending on a prior condition, theoretically the ir a + infinitive form is not used (p. 76, our italics).

In short, if this were true, the variable expression of future tense would be marked in Spanish by a question involving the confidence the speakers have in the facts they are expressing. As stated by Díaz Peralta and Almeida (2000: 217), who found a correlation of this type in the community in Las Palmas de Gran Canaria:

\begin{abstract}
... on a continuum of epistemic modality (...), the speaker chooses the form ending in -ré, the periphrastic construction, or the present indicative, depending on how much confidence is placed in the proposal contained in the statement. Maximum confidence that the action will take place is associated with the present (voy a "I'm going"), while the greatest uncertainty is associated with the synthetic future (iré "I'll go").
\end{abstract}

Expressing oneself with PF would make what the speaker says more precise and certain than the use of MF (Iuliano \& de Stefano, 1979). However, at the same time this variant has been related to the so-called deontic modality, which is concerned with will, intention, desire, and so forth. For example, Sedano (1994:235) has 
pointed out that in Venezuela "... although it is not easy to determine exactly how many sentences there are within the corpus with a first person singular subject in which the PF conveys a modality of intention, everything seems to suggest that the proportion is high." On the other hand, Bauhr (1992:77) considers that the periphrastic form in the first person is typically used to express what the speaker intends to do, that is to say, as a manifestation of his or her own will, regardless of what the interlocutor may wish or the possible pressure from other external factors.

We therefore find ourselves before one of those semantic factors that offers the greatest difficulties when it comes to establishing the true intentions of the speakers when they say what they say. Because it is impossible to gain access to their inner states of consciousness, we used the information provided by the context (whenever possible) to classify the occurrences of the future on an attitudinal scale. This information was then used to make a distinction between the following possibilities.

1. Future events or states that the speaker is absolutely sure will happen or that necessarily derive from the very nature of things. This is the case, for example, in the following fragments:

(38) ... porque así, siempre estás, "ay mira, ahora llegarán las vacaciones de Navidad; ay mira, pues ..." (215/800)

... because like that you're always thinking, "oh look, now the Christmas holidays are coming; oh look, so ..."

(39) Tú te vas a levantar el uno de enero, y vas a seguir siendo la misma Rosa $(276 / 815)$

You're going to get up on the first of January, and you're still going to be the same Rosa

2. Future events or states the speaker cannot be sure of, because there is no guarantee that they are actually going to come about. With the help of the information provided by the context, however, we can distinguish a number of subdivisions within this group that we consider to be significant.

a. Future events or states that the participants (preferably the speaker and interlocutor) express an intention or wish to carry out:

(40) ... y como ya sabemos que a los toros hacen fiesta, pues nos quedamos ... nos quedaremos aquí y luego ... (334/845)

... and as we know bulls liven up the festivities, so we're staying ... we'll stay here and then ...

(41) ... pero tienes que ... aprender un poco a decir: "bueno voy a separar y ahora estoy con mis amigos ..." (126/901) ... but you have to ... learn to sort of say, "Well, I'm going to make a separation and now I'm with my friends ..."

b. Future events or states that the speaker gives an opinion about. We make a further distinction between two types within this group, depending on the degree of conjecture linked to such opinions. 
i. The first is represented by future events or states about which the speaker displays a higher degree of uncertainty, doubt, fear, and so on. To obtain these cases, we used various contextual factors, such as (a) the semantics of certain verbs (dudar, suponer... "doubt, suppose"), (b) the use of doxastic predicates (me parece, creo que, pienso ... "it looks like, I believe that, I think"), or (c) the presence within the surrounding linguistic context of markers that have an attenuating function (bueno, en fin, pues, ¿no?, no sé, a lo mejor ... "well, anyway, so, right?, I don't know, probably"). Within this subgroup, we also include contingent events, that is, those whose occurrence in the future depends on a condition, which makes them even more hypothetical in nature. In Spanish, this semantic framework is achieved, for example, by means of the utilization of conditional sentences, usually with $s i$ (if) in the protasis (si vienes ... "if you come ..."), although the condition is often inferred from the communicative situation:

(42) ... a lo mejor el día que tenga niños, a lo mejor me informaré más (326/ 924)

... probably the day I start having children, I'll probably seek more information

(43) ... ¿este verano? Pues este verano creo que me voy a quedar en mi casa (risas) $(351 / 972)$

... this summer? Well, this summer I think I'm going to stay at home [laughs]

ii. All the other cases, in which the speaker expresses opinions that are apparently not conditioned by the previous factors, which suggests a higher degree of confidence:

(44) ... no exactamente, sino que vi y digo "ahí hay peligro si cojo la curva muy rápido me saldré" (54/983)

... not exactly, really I saw and said "that's dangerous there, if I go into the bend too fast I'll go off the road"

(45) ... a uno que ha hecho ingeniería lo van a coger porque tiene una carrera antes que uno de FP o uno de BUP

... they're going to take on someone who's studied engineering before somebody from secondary school or vocational training because they've got a degree

After performing the multivariate analysis, this factor was also found to be one of the most significant (range 30). The probabilistic data, however, show that only the events classified as being uncertain (i) favor the choice of MF (0.62), whereas all the others disfavor it. Again, the fact that the future events are very often expressed with notable amounts of conjecture helps to explain the considerable presence of MF in our sample as a whole. Indeed, this type of context accounts for $44 \%$ of the total number of occurrences of the future tense in the corpus.

On the other hand, it comes as no surprise to find that PF is clearly preferred to express facts that the speakers are more certain about (0.60). However, additionally, even the less hypothetical opinions - that is to say, the ones that are less marked by 
conjecture and doubt (ii)—show a preference for this variant (0.54). In short, the analysis confirms, above all, the poor association that exists between the morphological future and the semantic features of intentionality and the expression of the speaker's will (0.32), which are, in contrast, clearly related to the periphrastic variant.

Degree of animacy of the subject and text type. Unlike other Romance corpora, where the variability of future forms is, in some way, conditioned by the grammatical person (Orozco, 2005; Poplack \& Malvar, 2007), this factor was not chosen as being significant by the multivariate analysis in the Castellón corpus. Nevertheless, the semantic factor of agency, which is reflected in our research by means of the more objective trait of animacy, is significant and enables us to distinguish between three types of subjects.

1. Human subjects:

(46) ... lo que pasa que no pilla muy bien la fecha y no sé si nos podremos ir pero de todas maneras .... (123/1014)

the thing is that the date's not a particularly good one and I don't know whether we'll be able to go but anyway ...

(47) ... que si a(ho)ra me compro un coche, que si a(ho)ra me voy de viaje, a(ho)ra me voy a comer, a(ho)ra me voy ... (101/1012)

... now I'm going to buy a car, now I'm going away on holiday, now I'm going to have lunch, now I'm going ...

2. Second, we considered a group that, despite being made up of animated subjects, displays a lower degree of agency compared to the previous cases, because they do not refer directly to the participants in the communicative act but instead to generic indefinite entities. This is what happens in Spanish, for example, with certain uses of the second person singular $(t u ́)$ in generic or indefinite temporal contexts that do not refer to the interlocutor but rather an undefined entity (Vila, 1987). The same thing can be said of certain uses of the third person plural, which is taken in an indefinite sense with the necessary elision of the subject (Fernández, 1999:1218):

(48) ... lo que te gusta (i.e., "a cualquiera le gusta") es estar en la calle, tú estarás en la calle y un día te meterás con uno, otro día te meterás con otro $(236 / 1285)$

... what you like (i.e., "everybody likes") is to be out in the street, you'll be out in the street and one day you'll meet someone, another day you'll meet someone else

(49) ... y siempre vas pendiente del reloj "que... me van a cerrar aquí, que me van a cerrar allá, que esto..." (324/1313)

... and you're always looking at the time, "they're going to be closed when I get there, they're going to be closed in the other place too, and this and that ..."

3. Nonhuman subjects: 
(50) ... pero pienso que me saldrá en una ciudad [el trabajo], la verdad (129/ 1398)

... but I think [the job] will come up in a city, honestly

(51) ... si no juegas no te va a tocar [la lotería] (271/1421)

if you don't play [the lottery] you're not going to win it

As can be seen in Table 2, the results of the analysis show a slightly more moderate, but also significant, statistical weight this time (range 22). Nonhuman subjects are the only ones that favor the selection of MF (0.57), but semantically generic or indefinite ones clearly disfavor it (0.35). The other human subjects, however, show a neutral incidence (0.50).

Both the negative significance of semantically impersonal subjects in MF and the fact that both the second person singular and third person plural (where many of these uses are concentrated in Spanish) offer the lowest frequencies of usage of this variant ( $35 \%$ and $45 \%$, respectively) led us to consider a possible correlation between the variable expression of future tense and another structural factor, the text type. To check this intuition, we coded the future forms according to only two types of contexts (see note 4).

1. First, actions and states that the speaker projects toward the future in the course of argumentative passages, in which the speaker expresses an opinion about them. In Spanish, speakers frequently turn to impersonal strategies to express their opinions about certain topics. This is the case in (52) and (53), where speakers were giving their opinions about the possible introduction of a law that reduces the working week to 35 hours throughout the whole of Spain. The use of this kind of strategy is a characteristic attenuation resource by means of which speakers mitigate their responsibility regarding the value of their judgments, which they do not always feel sure about:

(52) pues ... me parece bien porque así yo creo que se dará trabajo a ... a más gente $(269 / 1544)$

well, that seems fine to me because like that I think more people will get a job

(53) ... eso no lo van a hacer por eso, porque es una tontería porque más puestos de trabajo no va a crear [una futura ley de 35 horas semanales de trabajo] $(281 / 1661)$

... that's not why they're going to do it, because it's stupid because [a future law introducing a 35-hour working week] isn't going to create more employment

2. In opposition to the previous cases, we constituted another block from the verb forms that arise in expository contexts, and in those in which the speaker talks about plans for the future (travels, summer holidays, weekends, etc.), as in (54) and (55):

(54) ... me dejaré historia porque es más fácil, psicología es muy complica(d)o $(296 / 1698)$

... I'll leave history for later on because it's easier, psychology is really complicated 
... por eso este año le voy a meter medio amago a mi madre, y me voy a quedar aquí hasta el 15 de julio, aunque termine el día 8 (296/1703) ... that's why this year I'm going to half con my mum and I'm going to stay here until the 15th of July, although I finish on the 8th

As expected, this factor is also found to be significant in the multivariate analysis, although with a less hierarchical value than the agency one (range 14). Furthermore, and also as expected, the argumentative passages are the ones that least favor the presence of MF (0.43) and, in contrast, most encourage the choice of PF. This is just the opposite of what happens in the case of expository fragments: when speakers express activities due to take place in the future (e.g., travel), they display a marked tendency to choose the inflectional variants in the Castellón speech communities (0.57).

Type of verb. Another of the linguistic criteria that was found to be one of the most significant (range 32) in the Castellón corpus is the semantic category of verbs. The most important factors that favor the use of MF are the modal verbs (poder "can," querer "want," deber "must," and so on): verbs that express things such as possibility, necessity, obligation, and so forth. The probabilistic weight reached by this factor is among the highest of all (0.75). Thus, the frequency of this variant in this type of context, as with those in (56), is four times $(79 \%)$ those of PF (21\%), as can be seen in (57):

... entonces no sé si podré pillarlas [las vacaciones] (282/1667)

... so I don't know if I'll be able to take any [days off]

¿va a querer tu hijo bajar contigo, cuando a ti te de la gana, a hablar con él? ... que no! $(327 / 51)$

Is your son going to want to go down with you, whenever you feel like it, to speak to him? ... No way!

It does not seem difficult to explain this result if we bear in mind the relations we observed above between the presence of the MF and more contingent or unreal content, that is, the ones the speaker feels more uncertain about whether they will take place or not (see earlier discussion of sentence modality). Indeed, on an epistemic modality continuum, modal verbs would lead the way among such contents, because they contain the values we are dealing with inside the lexeme itself, without the need for any kind of context.

Another class of verbs that favor the choice of MF are the verb periphrases with aspectual rather than modal content (soler [used to] plus infinitive, estar [be] plus gerund, tener [have] plus participle, and so forth), which also have one of the highest probabilistic weights $(0.64) .{ }^{7}$ Now the explanation could have to do with factors such as linguistic economy or stylistic awkwardness. Indeed, the expression of future events through the verbal periphrasis turns out to be simpler and more economical by MF than by PF. In this latter case, the linking of constituents (one periphrasis followed by another) encumbers expression, making it too complicated for the speaker. In this respect, compare example 
(58), from the corpus, with the equivalent form it would have if the periphrastic variant were used (59)—something that is possible but not recorded in our study:

... yo pienso que nos volveremos a ver, no sé cómo, pero nos volveremos a ver $(372 / 194)$

... I think we'll see each other again, I don't know how, but we'll see each other again

(59) ... yo pienso que nos vamos a volver a ver, no sé cómo, pero nos vamos a volver a ver

... I think we're going to see each other again, I don't know how, but we're going to see each other again

Lastly, a positive association can also been observed between MF and verbs of movement (ir "go," llevar "take," salir "go out," entrar "enter," marchar "leave," subir "go up," bajar "go down," caer "fall," and so forth) (0.63), and those involving sensory perception (ver "see," oir "hear," escuchar "listen," observar "observe," and so forth) (0.66). However, each of the two groups contains a verb that is used far more frequently than the others, and they are, therefore, the ones most responsible for the results obtained. The first is the verb ir (go) (62\% of all the verbs of movement) and the other is ver (see) (50\% of the verbs of sensory perception).

The greater tendency toward the use of MF (71\%) rather than PF (29\%) in the case of ir (or its equivalent form) has already been observed in other speech communities, within Spanish-speaking territories (Díaz Peralta \& Almeida, 2000; Orozco, 2005) and in other linguistic domains (see Poplack \& Melvar [2007] for Portuguese; Poplack \& Tagliamonte [2001] for early stages of the African American English; and Singler [1984] for Liberian English). A number of reasons, which can also be applied to the Castellón corpus, have been put forward to explain this. One of them is the actual historical evolution of the verb from its full movement-related meaning up to its function as an auxiliary verb in periphrases. The conflict between the two functions therefore seems to restrict the use of $i r$ when the speaker wishes to express future actions. Moreover, the repetition of the same lexical item that occurs in the PF between the main verb and the auxiliary (in both cases it is $i r$ ) may also explain why discourse contains fewer occurrences of examples like those in (60) than of those involving the morphological variant, as in (61) (although the former are nevertheless possible):

(60) ... que a la larga pos iremos todos a la calle [...] (328/67)

... so in the end we'll all get the sack

(61) ... pues mañana sábado me voy a ir a la biblioteca $(102 / 424)$

... so tomorrow, Saturday, I'm going to go to the library

As far as the verb ver is concerned, the preferences for MF (62\%) have now been shown by the frequency with which this verb appears in formulaic expressions, in 
which the modal connotations would be as (or more) important than the actual indication of prospective temporality itself (Orozco, 2005:61-62). In our research, we have removed all occurrences of the verb in which either the temporal idea is completely watered down or the choice of one variant or the other has been almost categorically fixed by usage (see the discussion of methodology). Despite these precautions, the distribution of the variants of this verb shows a tendency toward the inflectional form rather than for the periphrastic one.

Something similar has been claimed in the literature with respect to the verb ser (be), although overall the stative verbs no longer display a positive significance, in fact, it is now slightly negative (0.47). Nevertheless, on counting the occurrences of ser with a future value in our corpus, it could be seen how this verb in particular appears significantly more often in the inflectional variant form $(67 \%)$ than in the periphrastic form (33\%). Here, too, both the evolution of the verb ser throughout the history of Spanish (from its full meaning to its auxiliary role in a number of periphrases) and its frequent appearance in formulaic phrases (lo que tenga que ser será ... "what is to be, will be ...") could account for these differences in favor of MF.

As opposed to the preceding verbs, all the others that were considered in the analysis (eventive, factive, language, others) disfavor the choice of this variant and encourage the use of the periphrastic future.

Type of clause. To finish with the linguistic factors, we are also going to look at the possible influence of the syntactic context of the sentence on the alternation of future tenses. To this regard, we distinguish between two settings.

1. Future tense forms that appear in subordinate clauses, as in (62) and (63):

(62) ... pues, después de todo lo que he visto, no sé si no me apuntaré $(382 / 1198)$

... well, after everything I've seen, there's a good chance I might enroll

(63) ... esa es la única cosa que voy a hacer este verano (396/1209)

that's all I'm going to do this summer

2. The other sentences, because they are simple clauses, coordinated periods, or main propositions within the heart of sentences formed by subordination:

(64) ... pero este año me volveré a apuntar otra vez ahí en Grapa (134/1221)

... but this year I'll enroll again over there in Grapa

(65) ... no se va a coger a nadie para hacer dos horas extras $(134 / 1230)$

... they're not going to get hold of anyone to do two hours' overtime

Although it has a lower range than many of the other linguistic factors we have considered (19), this one is also significant in our speech community. Moreover, our probability data coincide remarkably well with those obtained by Díaz Peralta \& Almeida (2000) in their study about Las Palmas de Gran Canaria, as subordinate clauses clearly disfavored the morphological future in both corpora 
( 0.36 for the Canary Island corpus; 0.38 for the one from Castellón). Both these findings and those from other variationist studies (Matsuda, 1993; Tarallo, 1989) suggest that the attraction of subordinate contexts plays a minor role in processes of linguistic change.

\section{Nonstructural factors}

In spite of the generally lower overall statistical relevance of the social factors, the findings of the quantitative analysis reveal some correlations that are worth a closer look, because they could, at least partially, explain the notable vitality enjoyed by the inflectional variant in our speech community, in sharp contrast to what happens in other regions of the Hispanic world.

For the time being, it is enough to remark that factors that have traditionally been the first to be considered in studies into linguistic variation do not display any significance whatsoever, at least not when treated in isolation. Thus, when taken in isolation, neither level of education nor the type of professional activity is found to be significant by the multivariate analysis. In fact, the scarce differences observed inside each factor group are more closely related to other sociological factors, which we will now go on to consider.

One of these factors is age. Although initially the multivariate analysis did not select this factor as being significant, the distribution of frequencies of the four generational groups that our sample was divided into offered a characteristic profile that called for a deeper examination of the findings. As can be seen in Figure 1, there seems to be a genolectal gap in the Castellón community, consisting of a greater decline in the use of the inflectional variant among speakers under 40 years of age. In contrast, among older speakers, MF is still the preferred form. To check the statistical relevance of this division, we conducted a second multivariate analysis in which we put the first two age groups together on one side and groups three and four were placed on the other. The result of this new analysis was positive and confirmed our initial conclusion. That is, the older speakers favor the MF form (0.55), but it is disfavored by those in the younger age groups $(0.41)$.

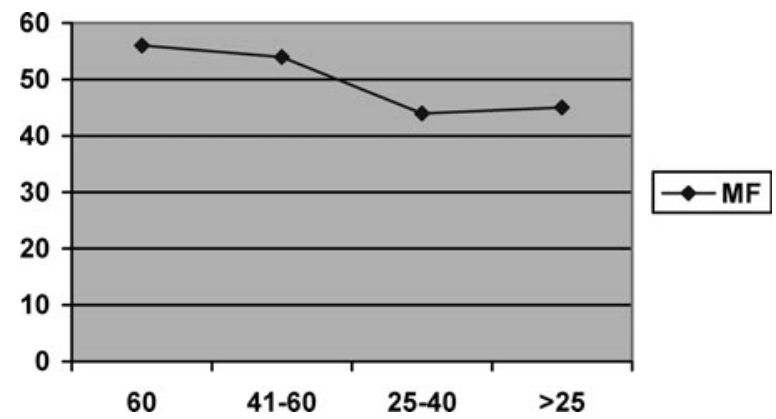

FIGURE 1. Distribution of the MF according to generational groups. 
The genolectal correlation between the variants of the future tense has also been found in other Hispanic corpora and in a similar line to that observed in this research. This has led some authors to talk of a linguistic change in progress (Díaz Peralta \& Almeida, 2000; Gutiérrez, 1995). In the case of another Spanish community - the city of Las Palmas de Gran Canaria-the differences between the age groups are not very pronounced, but they are also significant and display the same bias as in the Castellón region. Furthermore, the fact that they arise in a syntactic variable (which has a variability the speakers does not seem to be very aware of) could explain why the frequency distances are not greater.

This finding also enables us to account for certain idiosyncratic behaviors shown by some professional groups (type of profession or activity). Students, both in secondary education and at university, are among those who use MF with the lowest frequency, because they are nearly always respondents from the youngest age segments. In this case, the significant criterion does not seem to be related to the professional factor but rather to the age of the students.

Another factor that shows a positive significance on the alternation of future tenses is social status (range 15), which in this research was measured by crossing the different sociological criteria, such as level of education, type of profession, and level of income. Speakers situated on the highest level of the social scale-the upper middle class-disfavor the inflectional variants $(0.40)$, whereas the lower middle classes display a slight tendency in favor of using them (0.55). The lowest classes lie in a practically neutral position (0.49), thus tracing a curvilinear sociolectal profile. Together with the genolectal information discussed earlier, this could actually suggest the existence of a process of linguistic change in progress, in accordance with observations made in other areas of the Hispanic world.

Nevertheless, the significance displayed by this factor in our community differs from that seen in other regions, both in Latin America and in Spain. With respect to the former, for example, Manuel Gutiérrez $(1995,2002)$ conducted studies in diverse speech communities with Mexican origins, both in Mexico (Morelia, Mexico DF) and in the south of the United States (Houston). The results show that the swift advance of PF at the expense of MF is propelled significantly by the lower classes, within a sociolectal framework the author interprets as a change from below. Additionally, in Spanish cities such as Las Palmas de Gran Canaria, where MF seems to be displaying a renewed vitality, it is being encouraged by the upper classes, but not across the whole social spectrum; rather it is being bolstered by females from the first generations, and males appear to be more reluctant to change. This leads the authors of this research (Díaz Peralta \& Almeida, 2000) to defend the hypothesis of a change from above to account for the recovery of usages of MF, which is endorsed by some of the groups that most stand out when it comes to promoting linguistic changes based on the prestige of certain variants.

The robustness of this variant is also present in Castellón, but its diastratic profile is different. In our case, the decline in the use of MF is more pronounced 
precisely among the upper social strata, which are the ones that display a greater resistance to accepting this change in other dialectal domains. On the other hand, although, if taken in isolation, sex is not selected as a significant group factor, crossing it with social status shows how it is only the females in higher social positions who produce the most extreme percentages of PF at the expense of the inflectional variant, as can be seen in Table 4 .

As a result, if some process of linguistic change is taking place in our community (a rather risky conclusion given the data available), it would also be a process driven by the strata that are most sensitive to the sociolinguistic prestige attached to the variants. However, it is to the detriment of the one that supposedly conveys such prestige, because it is the most traditional and (presumably) educated form of the future tense in the Spanish verb system. Perhaps we should therefore search elsewhere for an explanation to these differences with respect to other speech communities. To do so, we will now go on to analyze the behavior of certain factors related to the speakers' ethnolinguistic context.

\section{The ethnolinguistic setting}

The main reason we wish to consider these factors is to examine the possible influence that the long-standing contact with another Romance language, Catalan, may have on the distribution of our variable in the speech community.

In the coastal areas of Castellón, ${ }^{8}$ the language we could consider to be autochthonous (because it was brought to the territories that were reconquered by the Crown of Aragon from the 13th century onward by settlers who were mostly of Catalan extraction) is Valencian, a dialectal variety of Catalan that is widely spoken throughout the Valencian region today. However, this language has coexisted alongside Castilian since at least the 16th century because of a process of linguistic substitution that has gone through different phases and intensities. Nevertheless, throughout the previous century, a characteristic diglossic distribution was established in which Castilian was the prestige language and Valencian was reserved for carrying out more domestic and less prestigious social functions. Yet, in recent decades, this situation has undergone

TABLE 4. Distribution of the variants after cross-tabulating social status and sex

\begin{tabular}{|c|c|c|c|c|}
\hline \multirow[b]{2}{*}{ Social status } & \multicolumn{2}{|c|}{ Females } & \multicolumn{2}{|c|}{ Males } \\
\hline & $\%$ & $(N)$ & $\%$ & $(N)$ \\
\hline Upper-middle & 36 & 88 & 45 & 115 \\
\hline Lower-middle & 50 & 293 & 54 & 153 \\
\hline Low & 52 & 184 & 46 & 224 \\
\hline
\end{tabular}

Note: The highest probabilities in each factor group are highlighted in bold type and the lowest are marked in italics. Probabilities that are identical or only have slightly significant differences appear unmarked. 
a number of important changes that have led to the social and official revitalization of the Catalan language. However, there are some important geographical differences in the use of this language. Thus, although Castellón de la Plana is the provincial capital that leads the way as far as the everyday usage of Valencian is concerned within the Valencian region, the highest rates of usage of this language are to be found in other towns and villages around the province.

Moreover, in spite of the structural proximity between Spanish and Catalan and the mutual influences they have on each other (Blas Arroyo, 2004), the two languages display certain differences as regards the way they express the future. These features will be examined in the following paragraphs.

First, in Catalan the infinitive periphrasis with the verb of movement (anar "go") has certain uses that are different to those of the equivalent structure in Castilian. With no preposition, anar plus infinitive is used for the canonical construction of the preterit, or simple past, tense and alternates with other simple variants (vaig cantar vs. cantí "I sang"), although in the Valencian dialect the first of these two forms is clearly more frequent than the second, at least as far as the spoken language is concerned. In short, the differences with respect to Castilian in this sense are important, because in this context, Spanish only makes use of simple forms. Observe the contrast between the following sentences:

(66) Ahir a la vesprada vaig arribar molt tard a la reunió-Catalan Yesterday afternoon I was very late for the meeting

(67) Ayer por la tarde llegué muy tarde a la reunión-Spanish

Yesterday afternoon $I$ was very late for the meeting

When accompanied by the preposition (anar a plus infinitive), the periphrasis becomes, as in Spanish, an infinitive periphrasis with an inchoative aspectual value and, more specifically, one that denotes a preparatory phase leading up to the action expressed by the verb (què anava a dir? "what was I going to say?") (Gavarró \& Laca, 2002:2692). Now, as pointed out by Badia (1985:1:394; 1994:615), the fact that these periphrases "look toward the future" does not justify their use to express the immediate or near future, unlike Spanish, where, as we have seen, this is not only possible but also very common. In any event, uses such as those in examples (68) and (69) have also spread into contemporary Catalan due to the influence of Castilian, but they are considered to be less genuine than the corresponding Catalan forms with the synthetic future tense (in brackets):

(68) Ara anem a veure el segon acte (comp. Ara veurem el segon acte)

Now we're going to/will see the second act

(69) Pareix que va a ploure (comp. Pareix que plourà)

It looks like it's going to/will rain

However, nothing is said about the use of this periphrastic form in other prospective contexts that are at a greater distance from the act of speech, which 
suggests that we are even further away now from the structural possibilities of the Catalan language, where the inflectional future is the basic form prescribed by its tense system. As stated by Gavarró \& Laca (2002:2694), despite the possible influence of Spanish (or the French spoken in the Roussillon region), "the uses that can be evidenced for anar $a+$ infinitive are but $a$ very small subset of the uses of the corresponding Spanish and French periphrases" (our italics).

In Catalan, the inflectional future also displays several significant differences compared to its equivalent uses in Spanish, especially as regards the way it can combine with other elements. Thus, whereas in Castilian the use of the subjunctive is compulsory in certain syntactic settings, such as subordinate time, modal, and relative noun clauses, in these same contexts Catalan makes use of the future tense, as can be observed in the following examples:

(70) Quan sentiràs que el tren arriba, surt a l'andana (Span. Cuando oigas que el tren llega, sal al andén)

When you hear the train approaching, go out onto the platform

(71) Ho faran com voldràn (Span. Lo harán como quieran)

They'll do it the way they want to

Now, in the same way language contact exerts an influence on the patterns of expression in the Catalan language, and based on the structural differences detected between the two languages, we might also ask whether it is possible for this influence to run in the opposite direction. Furthermore, we could examine whether this influence is capable of leaving quantitative traces that can be detected by means of a variationist analysis such as the one undertaken in this study.

If this were the case, the long steady contact between the languages over the centuries could be a key to explaining the enduring vigor of the inflectional future form in this bilingual speech community, with rates that are, as we have seen earlier, noticeably higher than those detected in other Spanish-speaking regions. In short, factors such as

the shared future tense form, with similar semantic and modal values, the wider range of syntagmatic possibilities such a variant allows in Catalan, and the functional specialization of the alternative form for other uses in this same language (i.e., the formation of the preterit)

could encourage converging expressive usages in the speech community, which would in turn curb the tendencies toward widespread rejection of the MF tense in favor of the periphrastic form attested in many Hispanic speech communities.

Yet, although appealing, this kind of explanation would not be enough, because the scarcity of similar variationist studies in other areas of the peninsula means that we would be lacking empirical arguments to confirm our hypothesis. Our data allow us to confirm that MF still enjoys a considerable degree of robustness in our speech community, but we do not have enough arguments to make us 
believe that it is greater or lesser than in other regions of Spain. This is because the small amounts of data available are usually limited to global counts, generally carried out using the written language, and are more often than not obtained using methods that do not always coincide with each other.

Despite the foregoing points, we believe that the possible influence exerted by the ethnolinguistic setting could be evaluated by means of a comparative analysis among different social groups related to relevant contextual factors.

The first of these is the speakers' place of origin, which in the Castellón corpus can be divided into three large groups:

1. Speakers who were born and have lived all or most of their lives in the town of Castellón de la Plana (capital).

2. Speakers who were born and have lived in the surrounding rural districts (province).

3. Speakers who are immigrants or whose parents were immigrants, and who moved to the town or village they live in after having already crossed the threshold for the formation of their respective linguistic repertories. (This is the control group.) Most of these immigrants come from either the southern regions of Spain (Andalusia, Castile-La Mancha) or from the neighboring region of Aragon. In any event, for the purposes of this research, any immigrants from other regions within the Catalan-speaking territories were removed from the corpus.

Despite the differences in the samples - the third group is smaller than the other two- the multivariate analysis offers some interesting data. On the one hand, the factor is selected as being significant and leads the field as far as extralinguistic factors are concerned (16), ahead of others considered earlier, such as age or social status. On the other hand, the probabilistic weights among groups are seen to diverge, mainly between those born in the small towns and villages of the province of Castellón, who display a slight tendency toward the use of MF (0.53) and immigrants or descendents of immigrants from other regions of Spain where Catalan is not spoken, who clearly disfavor this form (0.37). Speakers from the capital lie somewhere in between at a level that is practically neutral (0.49).

In short, the density of the linguistically autochthonous population seems to exert an effect on our variable. As was to be expected, the more widespread social use of the Catalan language in the rural areas, as compared to the town of Castellón de la Plana, where Spanish is still the more commonly used language, is reflected in the probabilistic data. However, these differences, although significant, are not very high, as should be the case in a province that is linguistically far more homogenous than the others in the Valencian region (Valencia or Alicante), where the divergences as regards the use of the autochthonous language between the respective provincial capitals and surrounding districts are much greater. In any case, these differences are far more evident in individuals who come from other regions of the peninsula and respond to our linguistic variable in a way that is presumably similar to that of 
their speech communities of origin. The fact that we are before a syntactic variable and, moreover, one that the speaker is not aware of would allow us to explain why this immigrant population has not assimilated the most common expressive habits of their host community, unlike what happens with other more visible, stereotyped expressive resources (discourse makers, conversational routines, emblematic uses of code switching, etc.)

Together with the place of origin of the members of the sample, we decided to complete the analysis by conducting an empirical study of the possible influence exerted by the ethnolinguistic affiliation of the respondents. To do so we made use of the factor we call dominant language, which was established using respondents' answers to two criteria that are often related, but do not necessarily coincide, namely, the mother tongue and the language most commonly used in the individual's day-to-day verbal interactions. After crossing the two criteria and removing a few intermediate cases, owing to their scant relevance, the sample was divided into two groups of speakers depending on the language that was predominant in their linguistic repertory:

1. Speakers whose dominant language was Spanish. Included in this group are a number of speakers who claim to be only passive bilinguals, because they always express themselves in Spanish, despite being perfectly capable of following a conversation in which the other participants are using Catalan.

2. Speakers whose dominant language was Catalan (always with some degree of active bilingualism).

Our hypothesis is that a stronger presence of Catalan in the speakers' repertory, and therefore a higher frequency of the verb schemas used in this language to form the future tenses, will also be reflected in the distribution of our variable in Spanish.

Our findings this time are not conclusive enough, although some data do point in a similar direction. First, the frequency analysis shows an advantage in favor of Catalan speakers as regards the use of MF (53\% vs. $45 \%$ for Spanish speakers). Nevertheless, the logistic regression analysis only found the factor to be significant (range 08) when it was considered in isolation, but not when it operated in combination with others.

A more detailed analysis of these results, however, suggests that this factor can at least partially account for the variability that is observed. This was performed by crossing this factor group with one of the linguistic factors considered earlier that achieved a higher degree of explanatory power, that is, the proximity to the act of speech. As seen before, MF was disfavored in the whole sample not only among close contexts but also (albeit to a different extent) among several distant contexts (intermediate, indefinite, attenuated). In fact, the presence of this variant was only clearly favored by the ones that are furthest away in time (see previous discussion of temporal distance).

So, to determine how the two ethnolinguistic groups behave in relation to this factor, we cross-tabulated the two criteria and the results can be seen in Figure 2. 


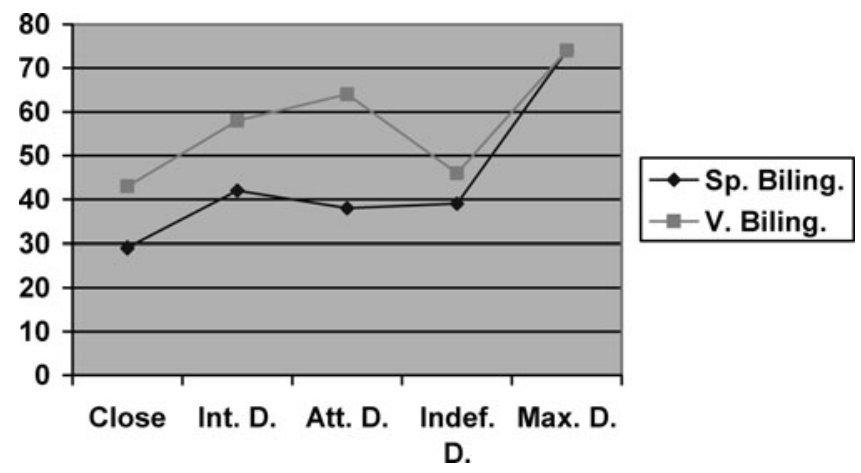

FIGURE 2. Distribution of the variants after cross-tabulating the speakers' dominant language and the proximity of the speech act.

As can be observed, except for the expression of the maximum distance, in the remaining contexts, speakers who have Catalan as their dominant language choose MF more frequently than the others, whether the contents are closer or more immediate ( $43 \%$ vs. $29 \%$ ) or more remote $(58 \%$ vs. $42 \%$ for the intermediate distance; $46 \%$ vs. $39 \%$ for the indefinite distance). This is also true, significantly enough, for those we classified as samples with an attenuated distance due to the presence of proximity markers within the linguistic context (64\% vs. 38\%).

It is revealing that the differences are more important in settings in which there is a greater structural conflict between Spanish and Catalan. Thus, even though both languages make more frequent use of the inflectional forms in contexts that are further away from the moment of speech, the probabilities of their being chosen diminish in Spanish as we approach this point. This idea of closeness can be either objective (in close contexts_iqué vas a hacer/harás esta tarde? "what are you going to do/will you do this afternoon?"-and intermediate ones-qué vas a hacer/harás este fin de semana? "what are you going to do/will you do this weekend?") or a kind of "psychological" proximity, such as that provided by certain markers in the discourse (¿qué harás/vas a hacer este verano? "what will you do/are you going to do this summer?"). Yet, in Catalan, these temporal settings also favor the use of the morphological future, and it therefore comes as little surprise to find that the increased frequency of use is more strongly associated to Valencian speakers than to Spanish speakers.

From the data obtained in this section, it can be inferred that certain factors associated to language contact (such as the density of the language communities within a territory or the greater or lesser competence and level of use of the speakers in each of the languages) can determine the development of a variable in a direction other than the one observed in other dialectal areas. In recent decades, many studies have drawn attention to the speeding up of certain linguistic changes in situations where social bilingualism exists, particularly when the balance is inclined in favor of one of the languages. Researchers such as Silva-Corvalán (1994) have highlighted the role these changes play as a 
catalyst in the Spanish spoken by Chicanos in the southern United States. Moreover, Gutiérrez (2002), who we mentioned earlier in relation to his studies on the future tense variable in Mexico and the United States, has provided empirical evidence to show that the general expansion of PF is significantly more advanced within the Spanish-speaking community in Houston (89\% vs. $4 \%$ and $7 \%$ for MF and the present tense, respectively) than among the Mexican populations in Morelia (73\% vs. $8 \%$ and $19 \%)$ and Mexico City (51\% vs. $26 \%$ and $23 \%$ ).

Yet, far less is known about the "conservative" role that this language contact frame may play in the retention of variants, which, in other dialectal domains, are subject to (sometimes very swift) changes, as is the case of the one under study here. Elsewhere we have written about this same role in relation to other linguistic variables within these same speech communities, which are characterized by the presence of typologically similar languages, such as Spanish and Catalan, and in which speakers make use of the most economical common solutions. This is the case, for example, with certain phonological variables such as the notable conservation of the intervocalic /-d-/ in contexts in which it is lost in other regions of the Spanish peninsula (pescado (pescao; acadado (acabao) (Blas Arroyo, 2006) or the special articulatory tension that causes educated consonantal groups ([eksámen, ak(jón]) to be maintained, whereas in other dialects they tend to become relaxed or weakened (egsámen/

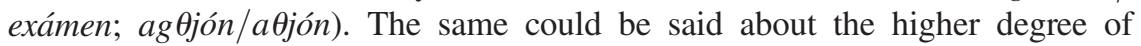
retention within these regions of the final phonemes in certain borrowings, where two consonants are in contact (carnets, chalets, clubs, yogurs), which is syntagmatically possible in Catalan but not in Spanish (Blas Arroyo, 2004).

In our opinion, something similar could be said of the grammatical variable under consideration in this study, as some authors had pointed out when referring to the Spanish spoken in these regions (Ramírez \& Blas Arroyo, 2000; Wesch, 1997), a hypothesis that is now supported by the empirical data from this research.

\section{CONCLUSIONS}

As in other Spanish-speaking regions and in areas where other Romance languages are spoken, the future tense variant is also declining in the Spanish spoken in the Castellón speech community and has, in general terms, now been overtaken in terms of frequency of use by PF.

Moreover, and in the same line of argument as that defended by other researchers, our empirical analysis confirms the fact that the expression of the future tense appears in our corpus as a linguistic variable, in the sense defined by the variationist approach (Poplack \& Turpin, 1999:7). This means that the inflectional future and PF forms (and possibly the present tense forms when they are used with a prospective value - a matter that is not considered in this work) behave as variants of a single linguistic expression and are sensitive to 
modifications that may take place in the variable context. Although, in our case, none of the variants are exclusive to any particular context, this does not mean that they will be chosen freely or in an idiosyncratic manner, because some factors play a significant role in accounting for variability.

The multivariate analysis enables us to observe how certain linguistic criteria that have already been highlighted in previous variationist studies play an important role in the tendency to give up the use of the MF tense in favor of the periphrastic variant. Some of the most important of these include the degree of proximity of the act of speech, the sentence and epistemic modality or the degree of adverbial specification. Others also worthy of mention are the class of verbs and, to a lesser extent, the semantic category of the subject (agency), and the type of clause and text.

In our community, the only factors that still clearly favor the choice of the inflectional future are the contexts that are more remote in time (hasta los treinta años tranquila que el chico no encontrará faena "you can be sure that the lad won't find a job until he's 30"), with some kind of adverbial specification, especially of an imprecise nature ("nunca piensas: 'cuando yo sea mayor ¿qué pasará?" "you never think, "what'll happen when I'm older?"'), or have a universal scope (¿No volverás a estudiar nunca ya? "Will you never start studying again?"). Similarly, those in which the speaker displays a higher degree of uncertainty or contingency with respect to whether the future acts will be performed or not (Hombre, saldremos, a lo mejor a dar una vuelta, sin más "Well, we will go out, but probably just for a stroll, that's all"). Likewise, both modal verbs (... ya no querrán venir con nosotros "they won't want to come with us any more") and periphrases (... pues no sé si la cabalgata la seguirán haciendo "well I don't know whether they still do the procession") like certain verbs of movement, particularly with the verb ir (go) (iré a Italia porque entiendo el italiano "I'll go to Italy because I understand Italian"), and of sensory perception (pero no sé si yo lo veré "but I don't know whether I'll see it") favor the choice of this variant. Nearly all the other factors taken into account in the analysis, however, disfavor it and therefore encourage the use of PF. Thus, this future tense also becomes the unmarked form for the expression of futurity in our community, that is to say, the one that is used to express later events regardless of any temporal or other adverbial clarification.

Nevertheless, despite the fact that both the evolutionary tendency and the factors involved in it are similar - with a few exceptions - to those found in other dialects, we cannot elude the notable fact that the morphological future still enjoys a substantial vitality in this linguistic region of the peninsula that is unknown in other areas. Both the overall figures and those obtained for some particular factors are quantitatively different from those observed in other places. Indeed, although most of the linguistic criteria discussed in the previous paragraph also favor the use of MF in other Hispanic speech communities, this variant is also much less common in those contexts. For example, in his research into this variable in Northern Colombia, Orozco (2005) observed that distance from the speech event favored MF (0.64). Yet, an analysis of the frequencies associated to 
each variant shows that, even in these remote contexts, MF is the less commonly used form ( $25 \%$ vs. $32 \%$ for the prospective present and $41 \%$ for PF).

In Castellón, however, the qualitative differences also have a quantitative correlate, so that the inflectional future is still chosen more frequently in a fair number of cases. Although the shortage of the same type of data about other regions of the peninsula does not allow us to make comparisons and therefore to obtain conclusive findings, we believe that an important part of this strength can be explained by the bilingual context in which this speech community finds itself immersed. Catalan (in its Valencian dialectal variety), which is the autochthonous language of the region and is spoken by most of the population, has lived alongside Spanish for centuries in this area. As Romance languages that are typologically very close to each other, Spanish and Catalan share a single variant for expressing the future, namely, the morphological form. Nevertheless, and unlike Spanish, Catalan reserves the periphrasis with anar (go) not only for certain inchoative aspectual values, but also, essentially, for the systematic expression of preterit actions and states. It is therefore logical to expect the speakers in the community to make use of the expressive possibilities offered by the community's repertory of languages, for the sake of economy. This in turn could account for the functional vitality that MF continues to enjoy in this region.

In addition to the generally high frequencies of use reached by this variant, which are unknown in other regions, some other data from our research also point in the same direction: toward the influence exerted by the linguistic contact context. We have therefore been able to observe how the inflectional variant is more favored in the rural districts of the province of Castellón, which are precisely the very same areas where the greatest part of the Valencian-speaking population is concentrated. In contrast, immigrants or descendants of immigrants from other parts of Spain outside the Catalan-speaking regions (Andalusia, Aragon, Castile-La Mancha) stand at the opposite end and tend to favor PF.

Furthermore, on researching into the relations between verbal variability and speakers' dominant language, the previous impression is bolstered even more. Although this time, the factor is not found to be significant in the multivariate analysis, a detailed study of its data reveals certain regularities that cannot be eluded and which can be interpreted in a similar manner. Thus, on comparing those who usually speak Valencian and those who normally use Spanish as regards the factor proximity to the act of speech, it can be seen how the former choose the inflectional variants more frequently than the latter in all time contexts, except the more distant ones.

Lastly, our hypothesis is favored if we consider the social significance of the variable and the differences that it also shows in this respect in relation to other speech communities in the Spanish-speaking world. In most of these, especially in Latin America and the United States, the evolution of this variable has been seen as a change from below, favoring the variants other than MF, but in Castellón, the sociolinguistic profile is just the opposite. Unlike the communities in the first case, where the upper classes are still hanging on to the inflectional future and preventing it from disappearing, in our peninsular corpus it is 
precisely these high social status groups that lead the way in the change in favor of PF. If we add the fact that within these wealthier classes, it is the females who are defending the change, we can deduce that these privileged sectors act against the morphological variant because they see it as being a vernacular variant, that is to say, as being the historically unmarked form used in the region. In contrast, these speakers would now consider the prestige variant to be the one that prevails outside the limits of their community, throughout the whole of the Spanish-speaking world: the periphrastic future.

\section{NOTES}

1. In both Spanish and other Romance languages, the MF tense has its origins in a Latin periphrasis (amare habeo) that came about as a result of the distinctive deficiencies that affected two homonymous verb tenses, namely, amabit and amabit. The elements of the periphrasis later merged formally to give rise to a synthetic form, which in turn was to see its usage gradually reduced due to competition from new periphrastic forms, especially ir a plus infinitive.

2. Nevertheless, in a few Latin American regions, the inflectional forms are still frequently produceda situation that could be explained by both language contact and/or by the relative isolation of these varieties from the current trends in the Spanish-speaking world (see de Granda [1997]; Escobar [1997]; Niño Murcia [1992] for discussion on the Spanish from the Andean region where it is in contact with Quechua and Aymara).

3. The first figure in parentheses identifies the number of the interview in the Corpus sociolingüístico de Castellón y sus comarcas, and the second refers to the line of the page where the example appears in the coded examples that were used as input data for the statistics program.

4. In two factor groups, the sum of the corresponding items does not match the total figure (1122), although due to different reasons in each case. Regarding social status, we decided not to use this factor for a few individuals in which the combination of the social characters (level of education, type of profession, and level of income) produces a result that is especially difficult to classify in the triadic social spectrum we establish for this study (see also Table 4). The type of text factor is altogether different. Now, this quantitative imbalance is a result of preventing those items from appearing in argumentative or expository sequences, but allowing them in other types of texts.

5. The semantic reasons are different in each case. In affirmative sentences, the speaker only expresses actions or states without any particular emotional involvement in their description. In the case of interrogative sentences, speakers expose an empty conceptual space that they expect will be filled by their interlocutor's answer.

6. It has occasionally been claimed that the use of one or another variant in the formulation of these imperative speech acts gives rise to certain pragmatic differences. According to Haverkate (1979:162), for example, MF is the unmarked form in formal texts, whereas PF is a more suitable formula for ordinary conversation because it is more indirect.

7. The periphrases with a modal content (obligation: tener que [have to] plus infinitive; deber [must] plus infinitive; haber de [have to] plus infinitive; probability: deber de [must] plus infinitive; poder [can] plus infinitive; etc.) are included in the previous group.

8. This is not the case of the inland strip of the region (Segorbe, Jerica, and so forth), which was reconquered by peoples from Aragon and not Catalonia. This fact explains why, historically, Valencian has not been spoken in these districts. Nevertheless, several centuries of intense contact between the two speech communities has given rise to a number of loans and mutual influences, which in the case of Spanish is described by the pejorative term churro or habla churra.

\section{REFERENCES}

Alcina, J., \& Blecua, J. M. (1975). Gramática española. Barcelona: Ariel.

Almeida, M., \& Díaz Peralta, M. (1998). Aspectos sociolingüísticos de un cambio gramatical: La expresión del futuro. Estudios Filológicos 33:7-22.

Álvarez, A., \& Barros, A. (1981). Los usos del futuro en las telenovelas. Video Forum 10:5-27. 
Ávila, R. (1968). Expresiones verbales de lo futuro y la caracterización social en dos obras del teatro mexicano contemporáneo. Archiv für das Studium der neueren Sprachen und Literaturem 204:346-349.

Badia, Margarit A. (1985). Gramática Catalana. Vol. 1. Madrid: Gredos.

(1994). Gramàtica de la llengua catalana descriptiva, normativa, diatòpica, diastràtica. Barcelona: Enciclopèdia Catalana.

Bauhr, G. (1989). El futuro en ré e ir a + infinitivo en el español peninsular moderno. Göteborg: Universidad de Göteborg.

(1992). Sobre el futuro cantaré y la forma compuesta voy a cantar en español moderno. Moderna Sprak 86(1):69-79.

Blanche-Benveniste, C. (1990). Le Français parlé: études grammaticales. Paris: Editions du CNRS.

Berschin, H. (1987). Futuro analítico y futuro sintético en el español peninsular colombiano. Lingüística Española Actual 9:101-109.

Blas Arroyo, J. L. (2000). Aspectos sobre la variación lingüística en la lengua escrita: La expresión de futuridad en el español literario. Lingüística Española Actual 22(2):161-200.

(2002). Laboratorio de Sociolingüística de la UJI: Materiales para la compilación y estudio de un macro-corpus sociolingüístico del español en las comunidades de habla castellonenses. In J. L. Blas Arroyo, M. Casanova, S. Fortuño, \& M. Porcar (eds.), Estudios sobre Lengua y Sociedad. Castellón: Servei de Publicacions de la Universitat Jaume I. 237-251. (2004). El español actual en las comunidades del ámbito lingüístico catalán. In Rafael Cano Aguilar (coord.), Historia de la Lengua Española. Vol. 2. Barcelona, Ariel. 1065-1086.

(2006). "Hasta aquí hemos llega(d)o": ¿Un caso de variación morfológica? Factores estructurales y estilísticos en el español de una comunidad bilingüe. Southwest Journal of Linguistics 25(2):39-74.

Bybee, J., \& Pagliuca, W. (1987). The evolution of future meaning. In A. Ramat, O. Carruba, \& G. Bernini (eds.), The evolution of future meaning. Amsterdam and Philadelphia: Benjamins. 107-122.

Cameron, R., \& Flores Ferrán, N. (2004). Perseveration of subject expression across regional dialects of Spanish. Spanish in Context 1(1):41-65.

Cartagena, N. (1978). Acerca de las categorías de tiempo y aspecto en el sistema verbal del español. Revista española de lingüística 8(2):375-408.

(1995-96). La inestabilidad del paradigma verbal de futuro, ¿hispanoamericanismo, hispanismo, romanismo o universal lingüístico? BFUch 35:79-100.

(1999). Los tiempos compuestos. In I. Bosque \& V. Demonte (eds.), Gramática descriptiva de la lengua española. Madrid: Espasa. 2935-2977.

Confais, J. P. (1995). Temps mode aspect: Les approches des morphemes verbaux et leurs problemes d l'exemple du français et de l'allemand. Toulouse: Presses Universitaires du Mirail.

Coseriu, E. (1973). Sincronía, diacronía e historia. El problema del cambio lingüístico. Madrid: Gredos. de Jonge, B. (1995). La interpretación de datos numéricos en el análisis lingüístico: Numerus omen est. Lingüística 3:15-35.

Díaz Peralta, M. (1997). Variación sintáctica y estilo discursivo: La expresión de la futuridad en el español de las Palmas de Gran Canaria. Lingüística Española Actual 19(2):185-197.

Díaz Peralta, M., \& Almeida, M. (2000). Sociolinguistic factors in grammatical change: The expression of the future in Canarian Spanish. Studia Neophilologica 72(2):217-228.

Eberenz, R. (1992). Futuro analítico y futuro sintético en tres obras con rasgos coloquiales: El "Corbacho," "La Celestina" y "La lozana andaluza." Homenaje a Hans Flasche: Festschrift zum 80:499-508.

Escobar, A. M. (1997). From time to modality in Spanish in contact with Quechua. Hispanic Linguistics 9(1):64-99.

Fernández, O. (1999). El pronombre personal: Formas y distribuciones. In I. Bosque \& V. Demonte (eds.), Gramática descriptiva de la lengua española. Madrid: Espasa. 1209-1274.

Fernández Ramírez, S. (1986). Gramática española. Madrid: Arco/Libros.

Fleischman, S. (1982). The future in thought and language: Diachronic evidence from Romance. Cambridge: Cambridge University Press.

Flores, L. (1964). El español hablado en Colombia y su atlas lingüístico. Vol. 1. Madrid: OFINES.

García Fernández, L. (1999). Los complementos adverbiales temporales. In I. Bosque \& V. Demonte (eds.), Gramática descriptiva de la lengua española. Madrid: Espasa. 3129-3208.

Gavarró, A., \& Laca, B. (2002). Les perífrasis temporals, aspectuals i modals. In J. Solà et al. (eds.), Gramática descriptiva catalana. Barcelona: Edicions de la Abadia de Monserrat. 2663-2726.

Gili Gaya, S. (1964). Curso superior de sintaxis española. Barcelona: Bibliograf. 
Givon, T. (1971). Historical syntax and synchronic morphology: An archaelogist's field trip. In D. Adams et al. (eds.), Papers from the Seventh Regional Meeting of the Chicago Linguistic Society, April 16-18. Chicago: Chicago Linguistic Society. 394-415.

Gómez Manzano, P. (1988). La expresión de futuro absoluto en el español hablado en Madrid y en México. Anuario de Letras 26:67-86.

González, J. M. (1983). Hacia una clasificación de la oración simple según el modus. Studia Philologica F. Lázaro Carreter. Madrid, Cátedra. 251-262.

Gougenheim, G. (1971). Etude sur les périphrases verbales de la langue française. Paris: A. G. Nizet. Granda, G. de (1997). Un fenómeno de convergencia lingüística por contacto en el quechua de Santiago del Estero: El desarrollo del futuro verbal perifrástico. Estudios Filológicos 32:35-42.

Grevisse, M. (1986). Le bon usage. Paris: Duculot.

Gutiérrez, M. (1990). Español de Michoacan/Español de Los Angeles: Tendencias de un proceso de cambio lingüístico. Ph.D. dissertation, University Southern California. . (1994). La influencia de "los de abajo" en tres procesos de cambio lingüístico en el español de Morelia, Michoacan. Language Problems and Language Planning 18(3):257-269.

(1995). On the future of the future tense in the Spanish of the Southwest. In C.Silva-Corvalan (ed.), Spanish in four continents: Studies in language contact and bilingualism. Washington, DC: Georgetown University Press. 214-226.

(2002). Innovación en el español de los Estados Unidos: ¿Progreso o decadencia? Revista de Lingüística Teórica y Aplicada 40:113-128.

Haverkate, H. (1979). Impositive Sentences in Spanish: Theory and Description in Linguistic Pragmatics. Amsterdam: North Holland.

Hernández, C. (1971). Sintaxis española. Valladolid, Spain: University of Valladolid.

Hopper, P. J., \& Traugott, E. C. (1993). Grammaticalization. New York: Cambridge University Press. Iuliano, R. (1976). La perífrasis ir a + infinitivo en el habla culta de Caracas. In M. Frances et al. (eds.), 1975 Colloquium on Hispanic Linguistics. Washington DC: Georgetown University Press. 59-69.

Iuliano, R., \& de Stefano, L. (1979). Un análisis sociolingüístico del habla de Caracas: Los valores del futuro. Boletín de la Academia Puertorriqueña de la lengua española 7:101-109.

Kernan, K., \& Blount, B. (1966). The acquisiton of Spanish grammar by Mexican children. Anthropological Linguistics 1:56-67.

Lamíquiz, V. (1986). Contrastes en el uso verbal: Habla de México y habla de Sevilla. In Actas del II Congreso Internacional sobre el español de América. Mexico D.F. January 27-31 1986.

(1987). Lengua española: método y estructuras lingüísticas, Barcelona, Ariel.

Lope Blanch, J. (1983). La reducción del paradigma verbal en el español de México. In J. Lope Blanch (ed.), Estudios sobre el español de México. México, UNAM. 145-159.

López García, A. et al. (1988). Lengua española. Valencia: Mestral.

Lyons, C. (1978). A look into the Spanish future. Lingua 46(2-3):225-244.

Marcos Marín, F. (1984). Curso de gramática española. Madrid: Cincel.

Matsuda, K. (1993). Dissecting analogical leveling quantitatively: The case of the innovative potential suffix in Tokyo Japanese. Language in Society 18:213-234.

Milroy, L. (1987). Observing and analyzing natural language. Oxford: Basil Blackwell.

Molho, M. (1975). Sistemática del verbo español. (Aspectos modos tiempos). Madrid: Gredos.

Montes Giraldo, J. (1962). Sobre la categoría de futuro en el español de Colombia. BICC 16:527-555.

Moreno de Alba, J. (1970). Vitalidad del futuro de indicativo en la norma culta del español hablado en México. Anuario de Letras 8:81-102.

(1978). Valores de las perífrasis verbales en el español de México. México, UNAM.

Naerssen, M. (1983). Ignoring the reality of the future in Spanish. Second Language Acquisition Studies 4:56-67.

Niño Murcia, M. (1992). El futuro sintético en el español norandino: Caso de mandato atenuado. Hispania 5:705-713.

Oroz, R (1964). El español de Chile. In Presente y futuro de la lengua española. Vol. 1. Madrid: OFINES

Orozco, R. (2005). Distribution of future tense forms in Northern Colombian Spanish. In D. Eddington, (ed.), Selected Proceedings of the 7th Hispanic Linguistics Symposium, Somerville, MA: Cascadilla Proceedings Project. 56-65.

Paufler, H. (1977). Lateinamerikanisches Spanish, Phonetisch-phonoloische und morphologischsyntakitsche. Leipzig, Germany: Fragen. 
Pereira-Scherre, M. (2001). Phrase-level parallelism effect on noun phrase number agreement. Language Variation and Change 13(1):91-107.

Poplack, S., \& Malvar, E. (2007). Elucidating the transition period in linguistic change. Probus 19(1): $169-199$.

Poplack, S., \& Tagliamonte, S. (2001). African American English in the Diaspora. Oxford: Basil Blackwell.

Poplack, Shana \& Turpin, Danielle. (1999). Does the FUTUR have a future in (Canadian) French? Probus 11(1):133-164.

R.A.E. (1973). Esbozo de una nueva gramática de la lengua española. Madrid: Espasa-Calpe.

Ramírez, M., \& Blas Arroyo, J. L. (2000). La expresión variable del futuro verbal en el español castellonense. In $V$ jornadas de fomento a la investigación. Castellón: Servei de Publicacions de la Universitat Jaume I (CD-ROM edition).

Robinson, J., Lawrence, H., \& Tagliamonte, S. (2001). GoldVarb 2001. A Multivariate Application for Windows. York: University of York.

Rojo, G. (1974). Perífrasis verbales en el gallego actual. Verba, appendix 2. Santiago: Universidad de Santiago de Compostela.

Rojo, G., \& Veiga, A. (1999). El tiempo verbal. Los tiempos simples. In I.Bosque, \& V.Demonte (eds.), Gramática descriptiva de la lengua española. Madrid, Espasa. 2867-2935.

Sáez Godoy, L. (1968). Algunas observaciones sobre la expresión del futuro en español. In Quilis, A. (ed.), Actas del XI Congreso Internacional de Lingüística y Filología Románicas. Vol. 4. Madrid. 1874-1889.

Sánchez, L., \& Ferrer, M. C. (1990). Algunos aspectos de la expresión de futuro. Paper presented at the IX Congreso Internacional de la ALFAL, Campinas (Brazil): Instituto de Estudos da Linguagem, 1990.

Schwegler, A. (1990). Analyticity and syntheticity: A diachronic perspective with special reference to Romance languages. New York: Mouton de Gruyter.

Sedano, M. (1994). El futuro morfológico y la expresión ir a + infinitivo en el español hablado de Venezuela. Verba 21:225-240.

Silva-Corvalán, C. (1994). Language contact and change. Oxford: Oxford University Press.

Silva-Corvalán, C., \& Terrell, T. (1989). Notas sobre la expresión de futuridad en el español del Caribe. Hispanic Linguistics 2(2):191-208.

Singler, J. V. (1984). Variation in tense-aspect-modality in Liberian English. Ph.D. dissertation, Los Angeles: University of California.

Söll, L. (1968). Synthestisches und analytisches futur im modernen Spanischen. Romanische Forschungen 1:239-248.

Sundell, L.G. (1991). Le Temps futur en français moderne. Uppsala: Textgruppen, Uppsala AB.

Tarallo, F. (1989). Inside and outside relative clauses. In R. Fasold \& D. Schiffrin (eds.), Language change and variation. Washington: Georgetown University Press. 255-274.

Troya, M. (1998). Perífrasis verbales de infinitivo en la norma lingüística culta de Las Palmas de Gran Canaria. Madrid-Las Palmas: Real Academia Española/Editorial de La Universidad de Las Palmas de Gran Canaria.

Ultan, R. (1978). The nature of future tenses. In Greenberg, J. H. (ed.), Universals of human language. Vol. 3: Word structure. Stanford, CA: Stanford University Press. 83-123.

Valdez, C. (1969). Perífrasis de infinitivo en la norma lingüística culta de ciudad de México. México D.F.: UNAM.

Vidal de Battini, B. (1964). El español de Argentina. In Presente y futuro de la lengua Española. Vol. 1. Madrid: OFINES.

Vila, M. R. (1987). La segunda persona gramatical en función no deíctica. Revista de la Sociedad Española de Lingüística 17(1):57-68.

Wagner, R. L., \& Pinchon, J. (1974). Grammaire du francais classique et moderne. Paris: Hachette.

Wesch, A. (1997). El castellano hablado de Barcelona y el influjo del catalán. Esbozo de un programa de investigación. Verba 24:287-312.

Zentella, A. C. (1990). Defining social and linguistic variables in the study of subject pronouns in U.S. Spanish. Paper presented at the XI Congreso Internacional sobre "El español en los Estados Unidos.", Chicago, October 1990.

(1997). Growing up bilingual: Puerto Rican children in New York. Malden, MA: Blackwell. 